\title{
Peroxisomes contribute to reactive oxygen species homeostasis and cell division induction in Arabidopsis protoplasts
}

\author{
Terence W.-Y. Tiew, Michael B. Sheahan ${ }^{\dagger}$ and Ray J. Rose* \\ School of Environmental and Life Sciences, The University of Newcastle, Callaghan, NSW, Australia
}

The ability to induce Arabidopsis protoplasts to dedifferentiate and divide provides a convenient system to analyze organelle dynamics in plant cells acquiring totipotency. Using peroxisome-targeted fluorescent proteins, we show that during protoplast culture, peroxisomes undergo massive proliferation and disperse uniformly around the cell before cell division. Peroxisome dispersion is influenced by the cytoskeleton, ensuring unbiased segregation during cell division. Considering their role in oxidative metabolism, we also investigated how peroxisomes influence homeostasis of reactive oxygen species (ROS). Protoplast isolation induces an oxidative burst, with mitochondria the likely major ROS producers. Subsequently ROS levels in protoplast cultures decline, correlating with the increase in peroxisomes, suggesting that peroxisome proliferation may also aid restoration of ROS homeostasis. Transcriptional profiling showed upregulation of several peroxisome-localized antioxidant enzymes, most notably catalase (CAT). Analysis of antioxidant levels, CAT activity and CAT isoform 3 mutants (cat3) indicate that peroxisome-localized CAT plays a major role in restoring ROS homeostasis. Furthermore, protoplast cultures of pex11a, a peroxisome division mutant, and cat3 mutants show reduced induction of cell division. Taken together, the data indicate that peroxisome proliferation and CAT contribute to ROS homeostasis and subsequent protoplast division induction.

Keywords: Arabidopsis, cell division, cytoskeleton, peroxisomes, Nicotiana, protoplasts, reactive oxygen species, totipotency

This article was submitted to Plant Cell Biology, a section of the journal Frontiers in Plant Science

Received: 07 May 2015 Accepted: 10 August 2015 Published: 26 August 2015

Citation:

Tiew TW-Y, Sheahan MB and Rose RJ (2015) Peroxisomes contribute to reactive oxygen species homeostasis and cell division induction in Arabidopsis protoplasts.

Front. Plant Sci. 6:658. doi: $10.3389 /$ fpls.2015.00658

\section{Introduction}

Plant protoplasts provide an invaluable experimental system to study cellular processes such as signal transduction (Sheen, 2001), cell wall regeneration (Leucci et al., 2007), the role of stress and hormones (Pasternak et al., 2002) and transient gene expression (Yoo et al., 2007). Protoplasts are well suited for investigating organelles in plant cells, as they provide many cytological benefits not available to multicellular tissues and suspension-cultured cells that commonly exist in clusters. More importantly, differentiated protoplasts can be induced to acquire totipotency and regenerate (Takebe et al., 1971; Chupeau et al., 2013), providing a convenient system to analyze organelle dynamics and inheritance in plant cells. In this system we have previously examined chloroplasts, the endoplasmic reticulum (ER; Sheahan et al., 2004), mitochondria (Sheahan et al., 2004, 2005), and vacuoles (Sheahan et al., 2007a); particularly in relation to the cytoskeleton. These studies have 
provided insights into the proliferation and inheritance of these organelles and the identification of "massive mitochondrial fusion." Given the significance of peroxisomes in plant metabolism (del Rio et al., 2006; Palma et al., 2009; Hu et al., 2012), we have investigated the dynamics of peroxisomes in cultured protoplasts acquiring totipotency in relation to proliferation, inheritance and reactive oxygen species (ROS) homeostasis.

Peroxisomes are ubiquitous in most eukaryotic cells (Baker and Graham, 2002) and in plant cells, are essential for the oxidation of fatty acids, photorespiration, biosynthesis of hormones and in ROS metabolism (Beevers, 1979; Johnson and Olsen, 2001; Hayashi and Nishimura, 2003; Nyathi and Baker, 2006; Hu et al., 2012). Peroxisomes are metabolically plastic organelles which adapt their enzyme content in response to developmental, metabolic and environmental cues via the import of new proteins rather than de novo synthesis of new organelles (Hayashi et al., 2000; Kaur and Hu, 2009; Palma et al., 2009). A defining feature of all peroxisome types (for which they are named), is their participation in the production and degradation of hydrogen peroxide through flavin-linked oxidases and catalase (CAT) respectively (Pracharoenwattana and Smith, 2008). Peroxisomes generate ROS, but can also rescue cells from the damaging effects of ROS. Accordingly, peroxisomes are the main site for renewal of cellular antioxidants and house an arsenal of antioxidant enzymes in addition to CAT, including superoxide dismutase, ascorbate peroxidase (APX), glutathione, and thioredoxin reductases (Lopez-Huertas et al., 2000; Corpas et al., 2001; Eubel et al., 2008).

For the nucleus, the initiation of a cell division cycle coordinates the ordered interaction of duplicated chromosomes with a microtubule (MT)-based spindle, ensuring that the nuclear genome partitions with stringent equality to each daughter cell (Franklin and Cande, 1999). For extranuclear organelles such as chloroplasts, mitochondria and the ER, there also appear to be specific, cytoskeleton-dependent mechanisms that ensure their unbiased inheritance during cell division (Sheahan et al., 2004, 2007 b). However, little is known about processes that might act to ensure unbiased peroxisome inheritance in protoplasts initiating plant regeneration.

In Arabidopsis dividing suspension-cultured cells, peroxisomes replicate and segregate into daughter cells (Lingard et al., 2008). In dividing cells of onion roots peroxisomes redistribute into a ring circumscribing the inner edge of the expanding phragmoplast (Collings et al., 2003). However, the fact that all peroxisomal proteins are encoded by the nucleus and subsequently imported into the organelle suggests that peroxisomes may not need an active inheritance process (Subramani, 1993). Indeed, temperature sensitive yeast mutants that lack peroxisomes at the restrictive temperature can synthesize peroxisomes de novo if cells are placed at the permissive temperature (Waterham et al., 1993). However, there is no direct evidence for de novo synthesis in plants.

The induction of cell division in cultured plant protoplasts is associated with, and appears to require, an oxidative burst (Pasternak et al., 2002; Féher et al., 2008; Wang et al., 2011; Petřivalský et al., 2012). Thus, the dynamics of peroxisomes in cultured protoplasts may also reflect a response to excessive ROS. Excessive ROS can cause recalcitrance to regeneration, and processes to restore ROS homeostasis are required for efficient cell division (Cutler et al., 1991; Papadakis and RoubelakisAngelakis, 1999; Papadakis et al., 2001; Petřivalský et al., 2012).

Using confocal microscopy to monitor fluorescently labeled peroxisomes during culture of Arabidopsis (and Nicotiana) protoplasts, we documented a massive amplification of the peroxisome population. By using cytoskeletal inhibitors, we show that the uniform redistribution of peroxisomes primarily depends on the actin and not MT cytoskeleton and that perturbing peroxisome dispersion greatly increased the bias in peroxisome inheritance. ROS levels declined rapidly during early protoplast culture in a manner inversely correlated with the increase in peroxisome number. The expression of peroxisome-related transcripts involved in the ascorbate-glutathione cycle remained essentially stable and inhibiting glutathione biosynthesis had little effect on ROS levels. Expression of the CAT isoform 3 (CAT3) and total CAT activity, however, increased dramatically during protoplast culture. Inhibiting CAT and catalase 3 mutants (cat3) resulted in increased ROS levels in cultured protoplasts. Moreover, pex11a and cat3 mutants displayed a reduced induction of cell division compared to WT protoplasts cultures. The peroxisome dynamics may serve the functions of ensuring peroxisome maintenance and inheritance and facilitating an optimal redox subcellular environment for initiating totipotency.

\section{Materials and Methods}

\section{Constructs and Plant Material}

Arabidopsis (Arabidopsis thaliana ecotype Col-0) plants expressing a GFP fusion to peroxisomal multifunctional protein 2 (At3g06860; Cutler et al., 2000) were obtained from the ABRC (Arabidopsis Biological Resource Centre; CS84735). Arabidopsis plants expressing a mitochondria-localized mGFP5-ATPase fusion protein (Logan and Leaver, 2000) were the gift of Prof. David Logan. Homozygous Arabidopsis pex11a and cat 3 mutants were obtained from the ABRC with the stock number of SALK_038574C and CS327473 respectively. Kikume cDNA was amplified from the phKikGR1-S1 plasmid (Amalgam, Japan) using the primers $5^{\prime}$-CGGACGGGTCCGACCGGTTCAGCTTC GACATTCGCCGGCGGCGCGC-3' and 5'-ATTTGCGGCCG CTTACAGCTTCGACTTGGCCAGCCTGGGCAGG-3' which introduced an SKL (PTS1; peroxisome targeting signal 1) encoding sequence at the $3^{\prime}$ end of the cDNA and also SalI and NotI sites at the $5^{\prime}$ and $3^{\prime}$ ends, respectively. The resulting hKikGR1-SKL amplicon was cut by SalI/NotI and ligated into pENTR1A entry vector (Invitrogen, Carlsbad, CA, USA) before being recombined with the pMDC32 destination vector (Curtis and Grossniklaus, 2003) using LR clonase II enzyme (Invitrogen). The resulting pMDC32-hKikGR1-SKL construct was transferred into Agrobacterium tumefaciens (strain LBA4404) by electroporation and bacteria selected on LB agar with $50 \mu \mathrm{g} \cdot \mathrm{mL}^{-1}$ kanamycin selection. Tobacco (Nicotiana tabacum cv. Xanthi) was stably transformed using the leaf disk procedure of (Horsch et al., 1985) as described in Sheahan et al. 
(2004). Tobacco plants expressing a mitochondria-localized coxIV-GFP fusion protein (Köhler et al., 1997) were the gift of Prof Maureen Hanson. Data presented are for Arabidopsis unless otherwise indicated.

\section{Plant Growth Conditions}

Arabidopsis seedlings were grown horizontally in plates containing $0.5 \mathrm{x}$ Murashige and Skoog salts, $0.8 \%(\mathrm{w} / \mathrm{v})$ agar and $1 \%(\mathrm{w} / \mathrm{v})$ sucrose (Murashige and Skoog, 1962). Surfacesterilized seeds were positioned on plates and stratified for 2 days at $4^{\circ} \mathrm{C}$ before being moved to a controlled growth environment $\left(22 / 18^{\circ} \mathrm{C}, 16 / 8 \mathrm{~h}\right.$ photoperiod at $80 \mu \mathrm{mol}$ photons $\left.\mathrm{m}^{-2} \cdot \mathrm{s}^{-1}\right)$. Axenic cultures of tobacco shoots were established as described by Potrykus and Shillito (1986) and maintained in culture pots containing 1x MS medium, $0.8 \%(\mathrm{w} / \mathrm{v})$ agar and $1 \%(\mathrm{w} / \mathrm{v})$ sucrose in a controlled growth environment $\left(25^{\circ} \mathrm{C}, 16 / 8 \mathrm{~h}\right.$ photoperiod at $50 \mu \mathrm{mol}$ photons $\mathrm{m}^{-2} \mathrm{~s}^{-1}$ ).

\section{Protoplast Isolation and Culture}

Arabidopsis mesophyll protoplasts were isolated from the aerial portion of 9 to 11-days-old plants as described in Sheahan et al. (2005) and were cultured at high density $\left(\sim 2 \times 10^{5}\right.$ cells $\left.\cdot \mathrm{mL}^{-1}\right)$ in KM8p culture medium (Kao and Michayluk, 1975). Tobacco mesophyll protoplasts were isolated from the leaves of axenic cultures, 3 weeks after subculture, and cultured in a modified NT medium with a light intensity of $0.5 \mu \mathrm{mol}$ photons $\mathrm{m}^{-2} \cdot \mathrm{s}^{-1}$ (Thomas and Rose, 1983) as described in Sheahan et al. (2004). In freshly isolated protoplasts cortical and perinuclear arrays remain largely intact and on incubation the density of AFs increase and transvacuolar arrays become prominent (Sheahan et al., 2004). MT immunofluorescence investigations with Vicia hajastana protoplasts show that while there is an initial disruption of MTs they re-organise and contribute to cell division in the normal way (Simmonds et al., 1983).

\section{Inhibitor Treatments}

All inhibitors were obtained from Sigma (Sydney, NSW, Australia), except latrunculin B (Merck, Sydney, NSW, Australia) and oryzalin (Crescent Chemical Co., Singapore) and prepared as $1000 \mathrm{X}$ stock solutions in dimethyl sulfoxide (final concentrations: latrunculin $\mathrm{B} ; 1 \mu \mathrm{M}$, oryzalin; $10 \mu \mathrm{M}$, diphenyleneiodonium chloride; $25 \mu \mathrm{M}$, allopurinol; $200 \mu \mathrm{M}$, stigmatellin; $10 \mu \mathrm{M}$, myxothiazol; $10 \mu \mathrm{M}$ and carbonyl cyanide 3chlorophenylhydrazone; $0.5 \mu \mathrm{M}$ ) or water (final concentrations: 2-deoxyglucose; $2 \mathrm{mM}$, 3-amino-1,2,4-triazole; $10 \mathrm{mM}$ ). Protoplast cultures were exposed to inhibitors throughout the culture period for cytoskeletal inhibitors (latrunculin B, oryzalin) or for a $24 \mathrm{~h}$ period before analysis for inhibitors of the antioxidant machinery or ROS levels. Dimethyl sulfoxide [0.1\% $(\mathrm{v} / \mathrm{v})]$ or water was used as a control in all experiments. While there is a small effect on cell volume with LatB and Oryzalin as cells progress toward division, cytokinesis is inhibited by LatB (40\%) and by Oryzalin (80\%).

\section{RNA Extraction, cDNA Synthesis and qPCR}

Total RNA for each time point was isolated from protoplasts (3 mL) using an RNAqueous-micro kit (Ambion, USA) and
DNase treated. Synthesis of cDNA was performed with $1 \mu \mathrm{g}$ of total RNA, primed by oligo(dT), using a SuperScript III kit (Invitrogen). The cDNA was diluted 1:45 for quantitative realtime PCR (qPCR) reactions. All qPCR reactions were prepared using a CAS1200 robot (Qiagen) and run on a Rotor-Gene Q (Qiagen). Primers were designed using primer-BLAST ${ }^{1}$ such that at least one primer crossed an exon-exon boundary and that they produced amplicons of between 150 and 300 bp (Supplementary Table S1). Reactions were performed in duplicate using a qPCR mixture containing $0.3 \mathrm{U}$ Platinum Taq and $1.5 \mu \mathrm{M}$ SYTO9 fluorescent dye (Invitrogen). The qPCR cycling conditions were $94^{\circ} \mathrm{C}$ for $2 \mathrm{~min}$, followed by 40 cycles of $94^{\circ} \mathrm{C}$ for $15 \mathrm{~s}$, $57^{\circ} \mathrm{C}$ for $30 \mathrm{~s}$ and $72^{\circ} \mathrm{C}$ for $20 \mathrm{~s}$. A dissociation curve was generated at the end of every run to ensure product uniformity. Gene expression was normalized to expression of polyubiquitin 10 (At4g05320) and relative expression calculated using the Pfaffl method (Pfaffl, 2001) with PCR efficiencies determined by LinRegPCR (http://linregpcr.nl/; Ramakers et al., 2003). Results shown are means \pm SEM of at least three biological repeats and two technical repeats for each time point.

\section{Microscopy and Organelle Visualization}

Protoplasts were mounted in welled slides and imaged using a LSM510 confocal laser- scanning microscope (Zeiss, Jena, Germany) equipped with a $40 \mathrm{X}$ C-Apochromat water-immersion objective. For RSR (Redox Sensor Red) staining, cells were incubated with the stain $(1 \mu \mathrm{M})$ for $6 \mathrm{~h}$ before visualization. Green fluorescent protein or the green form of Kikume was visualized using the $488 \mathrm{~nm}$ Ar laser and BP500-530 filter, chloroplasts with the $543 \mathrm{~nm}$ He-Ne laser and a LP650 filter and RSR with the $543 \mathrm{~nm} \mathrm{He}-\mathrm{Ne}$ laser and BP565-615 filter. Images of protoplasts were acquired as z-stacks with a $1 \mu \mathrm{m}$ interval as in previous studies on mitochondria (Sheahan et al., 2004). At least four protoplast preparations derived from independent plants or plates of seedlings were used to obtain quantitative data, with at least 15 cells imaged in each replicate.

\section{Image Analysis}

To analyze peroxisome morphology we used 8-bit, greyscale $z$-stacks of half cells. Images were analyzed in ImageJ $1.47^{2}$ as described in Sheahan et al. (2004). Briefly, image scale was calibrated, the protoplast periphery was outlined (polygon selection tool) before limiting the threshold gray values between 25 and 254 and applying a binary threshold. The analyze particles function of Image J was used to assess peroxisome area, perimeter and number (particles with an area less than 2 pixels were excluded). For clustered or aggregated peroxisomes, the set threshold function was optimized at best to separate the individual peroxisomes. Clustering was defined as where three or more peroxisomes had touching faces in at least two optical sections, whereas cells with gross aggregation were defined as those having a large proportion of the peroxisome population sequestered in a localized region of cytoplasm. To assess peroxisome segregation outcomes, we compared the

${ }^{1}$ http://www.ncbi.nlm.nih.gov/tools/primer-blast/
${ }^{2}$ http://imagej.nih.gov/ij/ 
proportion of total peroxisomes, counted from serial optical sections (stacks), in each daughter cell half, using the 'analyze particles' function of ImageJ. Peroxisome inheritance was also assessed by comparing the volume of peroxisomes (calculated as the summed plan-area) in each daughter cell half. Plan area is calculated as the sum of the surface areas of each optical section, using at least 100 cells from three biological replicates. The proportion of mitochondrial GFP and RSR colocalisation was determined by overlaying the red (RSR) and green (mtGFP) channels in Photoshop CS5 (Adobe Systems, San Jose, CA, USA), with yellow (overlay) relative to the proportion of total RSR stain in a cell, using at least 12 cells from three biological replicates.

\section{Analysis of Ascorbate and Glutathione}

Approximately $20 \mathrm{mg}$ of protoplasts were collected by centrifugation, the supernatant removed and the cells immediately frozen in liquid nitrogen, before determining ascorbate and glutathione levels as previously described (Law et al., 1983; Griffith, 1985; Smith, 1985; Zhang and Kirkham, 1996). Samples were assayed at $24 \mathrm{~h}$ intervals, with at least three biological and two technical repeats examined for each time point.

\section{Measurement of Enzyme Activity}

Protoplasts $(600 \mu \mathrm{L})$ were collected by centrifugation, the supernatant removed and immediately frozen in liquid nitrogen. The activity of CAT, APX, and glutathione reductase (GR) was assayed essentially as described (Maruthasalam et al., 2010). Briefly, for assessment of CAT activity, the protoplast pellet was resuspended in $500 \mu \mathrm{L}$ CAT assay buffer $(50 \mathrm{mM}$ phosphate buffer $\mathrm{pH} 7.0,0.1 \mu \mathrm{M}$ EDTA) and the cells disrupted by pulse sonication (Hielscher sonicator UP50H; $3 \times 15 \mathrm{~s}$ at $80 \%$ amplitude and $0.5 \mathrm{~s}$ cycle). Disrupted cells were allowed to cool on ice before proceeding. Measurement was initiated by the addition of $\mathrm{H}_{2} \mathrm{O}_{2}$ (40 $\mathrm{mM}$ final concentration) and the decrease in absorbance of $\mathrm{H}_{2} \mathrm{O}_{2}$ monitored at $240 \mathrm{~nm}$ with a spectrophotometer (Thermo Spectronic BioMate 3) for $60 \mathrm{~s}$, with readings taken every $10 \mathrm{~s}$. Total CAT activity was calculated as $\mu \mathrm{mol}$ of $\mathrm{H}_{2} \mathrm{O}_{2}$ decomposed $\mathrm{min}^{-1} \cdot \mathrm{mg}^{-1}$ of fresh weight. To analyze APX activity, protoplasts were resuspended in a $500 \mu \mathrm{L}$ APX assay buffer $(50 \mathrm{mM}$ phosphate buffer $\mathrm{pH}$ 6.0, 0.1 $\mu \mathrm{M}$ EDTA, $0.5 \mathrm{mM}$ ascorbate) and sonicated. Measurement was initiated by the addition of $\mathrm{H}_{2} \mathrm{O}_{2}(20 \mathrm{mM}$ final concentration) and the decrease in absorbance of ascorbate at $290 \mathrm{~nm}$ was monitored for $60 \mathrm{~s}$, as described above, and APX activity calculated as $\mu \mathrm{mol}$ of ascorbate oxidized $\mathrm{min}^{-1} \cdot \mathrm{mg}^{-1}$ of fresh weight. To analyze GR activity protoplasts were resuspended in $500 \mu \mathrm{L}$ of GR assay buffer $(50 \mathrm{mM}$ phosphate buffer $\mathrm{pH} 7.8,0.1 \mu \mathrm{M}$ EDTA, $0.05 \mathrm{mM}$ NADPH) and sonicated. Measurement was initiated by the addition of GSSG (3 $\mathrm{mM}$ final concentration) and the decrease in absorbance of NADPH at $340 \mathrm{~nm}$ was monitored for $60 \mathrm{~s}$, as described above, and GR activity calculated as $\mu \mathrm{mol}$ $\mathrm{NADPH}$ oxidized $\mathrm{min}^{-1} \cdot \mathrm{mg}^{-1}$ of fresh weight. Measurements for enzyme activity were obtained from at least three biological replicates.

\section{Measurement of Reactive Oxygen Species Level}

Extracellular $\mathrm{H}_{2} \mathrm{O}_{2}$ production was measured in control, inhibitor-treated and mutant protoplast populations using a modification of the luminol-based chemiluminescence assay described by Murphy and Huerta (1990). At each time-point, $3 \mathrm{~mL}$ of protoplast suspension was collected by centrifugation $(100 \mathrm{~g}, 10 \mathrm{~min})$ and the resulting pellet resuspended in $1 \mathrm{~mL}$ of luminometry assay buffer $(0.6 \mathrm{M}$ mannitol, $10 \mathrm{mM}$ MES $\mathrm{pH} 7.0,1 \mathrm{mM} \mathrm{CaCl} 2,0.1 \mathrm{mM} \mathrm{KCl}$ ). Luminescence measurements were made on a luminometer (Berthold Lumat 953, Germany). To each tube, $5 \mu \mathrm{L}$ of $25 \mathrm{mM}$ luminol and $5 \mu \mathrm{L}$ of $10 \mathrm{U} \cdot \mu \mathrm{L}^{-1}$ horseradish peroxidase (type VI-A; Sigma) was added, the tube shaken briefly $(<1 \mathrm{~s})$ and luminol-dependent luminescence measured immediately. The assay time was $120 \mathrm{~s}$ with nine measurements taken for $5 \mathrm{~s}$ each. A buffer-only control (luminometry assay buffer, luminol and horseradish peroxidase) was run in parallel for every measurement. The average of the final seven values for the buffer control was subtracted from the average of the final seven values from the cells to obtain the final reading. To examine $\mathrm{H}_{2} \mathrm{O}_{2}$ production in macerated leaf tissues, a leaf disk, equivalent in fresh weight to the calculated mass of protoplasts $(\sim 50 \mathrm{mg})$ in the luminometry reaction, was sliced into $2 \mathrm{~mm}$ strips, immediately placed in luminometry buffer with pre-added luminol and horseradish peroxidase and the chemiluminescence measured. Alternatively, measurements for ROS levels (Figures 4B,D) spectrophotometry was used as described by Maruthasalam et al. (2010), with three biological replicates.

\section{Results}

\section{Mesophyll Protoplast Culture and Peroxisomes in Isolated Arabidopsis Protoplasts}

Arabidopsis mesophyll protoplasts dedifferentiate and undergo cell division during culture (Figure 1A). Peroxisomes in freshly isolated protoplasts are sparsely distributed and are in close association with the chloroplasts (Figure 1B). Though generally spherical (Figure 1C, top left), as is common for peroxisomes, there can be a diversity of shapes. Some elongated forms are evident (Figure 1C, top left; inset), a number of cells exhibited peroxisomes with fine and highly mobile threadlike extensions (Figure 1C, top right). Although less common, toroidal (Figure 1C, bottom left) and dumbbell forms (Figure 1C, bottom right) were also observed, with dumbbells possibly representing peroxisome-division intermediates. The average peroxisome area in the freshly isolated protoplasts was $2.2 \pm 0.11 \mu \mathrm{m}^{2}$.

\section{Peroxisome Proliferate During Protoplast Culture}

In fresh protoplast preparations, there were on average, $62 \pm 5$ (mean \pm SEM, $n \geq 100$ ) peroxisomes per cell. The number of peroxisomes increased dramatically over protoplast culture, however, increasing more than 10-fold by $96 \mathrm{~h}$ of culture (Figure 2D). Given their plan area (Figures 2A,F; Supplementary Figures S5A,C), some peroxisomes in early culture could have a 


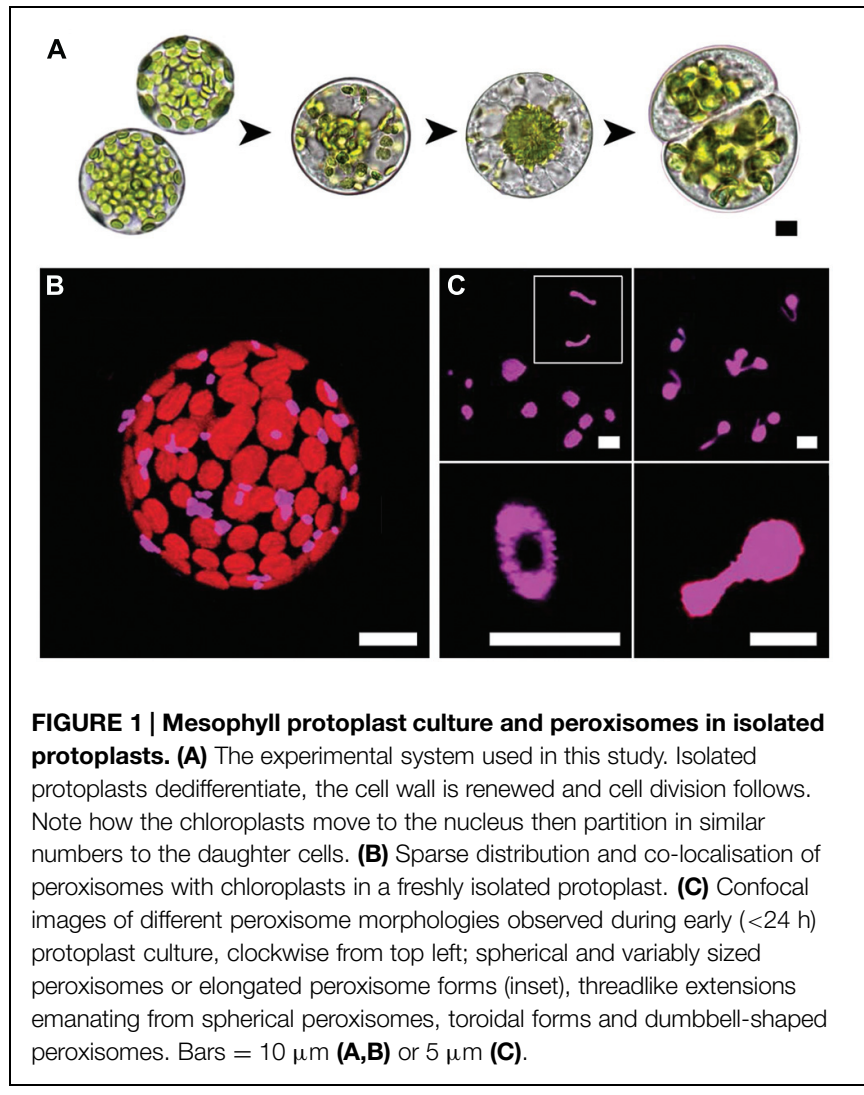

shape and orientation that would give a vertical length greater than $1 \mu \mathrm{m}$ and be counted twice. This would mean the starting number is slightly lower and making the $96 \mathrm{~h}$ fold increase slightly higher.

The total volume of peroxisomes per cell, as gaged by peroxisome plan-area (sum of peroxisome surface area from each $1 \mu \mathrm{m}$ section of a cell), also increased dramatically (Figure 2E); even though individual peroxisomal plan-area decreased during culture (Figure 2F). These changes increase the surface area of the peroxisome population and as such may facilitate a more efficient movement of molecules across the peroxisome membrane. The increased peroxisome numbers and surface areas is associated with increased expression of genes associated with the division and biosynthesis of peroxisomes (Supplementary Figure S1). As the peroxisomes increased in number, the changes to peroxisome distribution and morphology closely mirror those of mitochondria (Sheahan et al., 2005). Initially sparsely distributed, relatively large and clustered around chloroplasts (Figure 1B), peroxisomes dispersed near uniformly throughout the cytoplasm before the first cell division (Figures 2A-C).

\section{Peroxisome Inheritance During Protoplast Culture}

We surmised that the uniform dispersion of numerous peroxisomes might represent an inheritance strategy, similar to that of mitochondria (Sheahan et al., 2004). We therefore compared peroxisome inheritance in control and cytoskeleton-disrupted cells. In cells treated with the actin filament (AF)-disrupting agent, Latrunculin B (LatB; $1 \mu \mathrm{M}$ ), peroxisomes were less uniformly distributed compared to controls (Figures 3A,B), typically concentrating in localized regions of the cell and often co-localizing with chloroplasts. Peroxisomes in LatB-treated cells also formed larger aggregate complexes (Figure 3B). In cells treated with the MT-disrupting agent, oryzalin (Ory; $10 \mu \mathrm{M}$ ), peroxisome clustering and aggregation also appeared more prevalent relative to controls (Figure 3C), but not to the extent of LatB treatment. A random sampling of cells revealed that LatB-treated cells $(n=73)$ resulted in almost 1.5-fold more cells exhibiting clustered peroxisomes relative to controls $(n=89)$, whereas Ory-treated cells $(n=92)$ caused a more modest, 1.2-fold increase (Supplementary Figure S2). More importantly, LatB and Ory treatment increased the proportion of cells with grossly aggregated peroxisomes by 3.5and 1.9-fold relative to controls (Supplementary Figure S2). The number of peroxisomes in daughter cell pairs in symmetrically divided cells of control cultures, were shown to be uniformly distributed between daughter cells (Figure 3D). Accordingly, there was a small (6.6\%) deviation from equal inheritance (SD, $n=88$ cells; Figure 3G). The reduced number and less uniform distribution of peroxisomes in LatB- or Ory-treated protoplasts clearly affected inheritance outcomes (Figures 3E,F). In LatB- and Ory-treated protoplasts, the deviation from equal segregation was $21 \%$ ( $\mathrm{SD}, n=72$ cells) and $20 \%$ respectively, a 3 -fold increase in the segregation bias relative to controls. Most cell divisions in cytoskeleton-disrupted protoplasts were, however, asymmetric. In controls, $68 \%$ of divisions were symmetric, whereas the respective values for LatB- and Ory-treated protoplasts were 27 and 19\% (data not shown). An analysis of only symmetrically divided cells revealed a similar tendency for biased peroxisome segregation in LatBtreated cultures, with a bimodal distribution of inheritance frequencies (Figure 3H). In contrast, segregation bias in Ory-treated cultures was substantially reduced (Figure 3I). Analysis of peroxisome inheritance by peroxisome volume also generally reflected the results derived from peroxisome number.

\section{ROS Production Associated with Protoplast Isolation and Culture}

Stress-induced ROS has been suggested as an important inductive signal in plant cells acquiring totipotency (Pasternak et al., 2002; Féher et al., 2008; Faltin et al., 2010; Wang et al., 2011). Therefore, using chemiluminescence assays, we assessed extracellular $\mathrm{H}_{2} \mathrm{O}_{2}$ production in cultured mesophyll protoplasts. These assays revealed an elevated ROS production in freshly isolated protoplasts relative to macerated leaves (Figure 4A; Supplementary Figure S3A). During protoplast culture, however, measured levels of extracellular $\mathrm{H}_{2} \mathrm{O}_{2}$ decreased substantially, notably before significant rates of cell division were observed (Figures 4B,C; Supplementary Figures S3B,C). By utilizing RSR (a probe that labels subcellular ROS) to stain protoplast cell cultures, we confirmed the findings of the chemiluminescence analysis, with the proportion of RSR-stained mitochondria decreasing during protoplast culture 

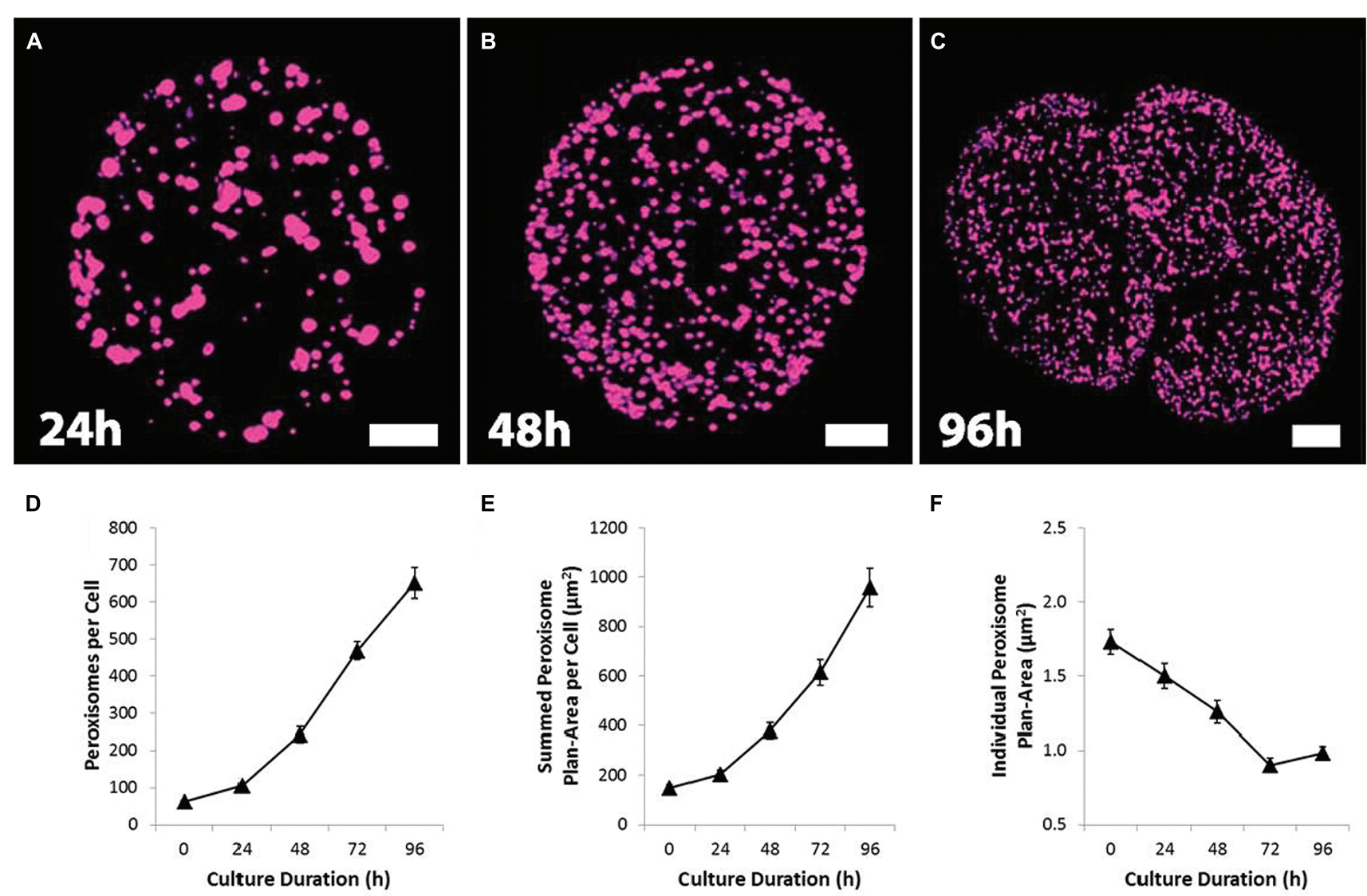

FIGURE 2 | Proliferation, dispersion and partitioning of the peroxisomes during protoplast culture and division. (A-C) Confocal projection images showing the change from a large, sparsely distributed peroxisome population to a small, numerous and uniformly dispersed population during protoplast culture, followed by protoplast division.
Bars $=10 \mu \mathrm{m}$. (D) Quantification of the number of peroxisomes showing the dramatic increase in peroxisome number during protoplast culture. (E) The total volume of peroxisomes per cell, gaged by integrating peroxisome plan-areas. (F) Quantification of peroxisome plan-area. Values are means \pm SEM with $n \geq 100$ (D-F).
(Figures 5A-D; Supplementary Figure S4). There was a strong, negative correlation between ROS level and peroxisome number in protoplasts (Figure 4D; Supplementary Figure S3D). These results indicate that ROS levels are perturbed by protoplast isolation, but then ROS homeostasis is largely restored before cell division and concomitant with an increase in peroxisome number.

\section{Source of ROS and Mechanisms of Homeostasis}

To further investigate the nature of the homeostatic mechanisms in operation to regulate ROS levels in protoplasts, we investigated the source of ROS production by applying agents that inhibit ROS production from different cellular sources (Table 1). As expected application of DPI inhibited ROS production almost entirely, given that DPI inhibits flavoproteins particularly NADPH oxidase and mitochondria NADH-ubiquinone oxidoreductase (Li and Trush, 1998; Riganti et al., 2004). Inhibition of glycolysis by 2 -DOG also resulted in decreased ROS production, whereas inhibition of xanthine dehydrogenase-oxidase, a cytosolic enzyme that produces $\mathrm{H}_{2} \mathrm{O}_{2}$, had little impact on ROS levels.
Surprisingly, however, inhibitors of mitochondrial electron transport also dramatically reduced ROS production, as did the uncoupling agent CCCP. In the case of stigmatellin the contribution of chloroplasts would be minimal as the light intensity is very low and chloroplasts are dedifferentiating toward proplastids (Thomas and Rose, 1983). Overall these findings suggest that mitochondria are the major contributors to the extracellular $\mathrm{H}_{2} \mathrm{O}_{2}$ measured in protoplast cultures. Consistent with these data are the overlayed confocal images of RSR stained protoplast cultures with GFP-labeled mitochondria (Figure 5E) at the beginning of the incubation period, when mitochondria stain with RSR as a result of ROS production and before the mitochondria become reduced as ROS is detoxified.

\section{What Drives the Reduction in ROS Levels before the Onset of Cell Division?}

Since cellular ROS levels represent a balance between ROS generation and degradation, the reduction in ROS level observed may result from decreased ROS generation or increased antioxidant capacity. Enzymatic antioxidants that catalyze the 

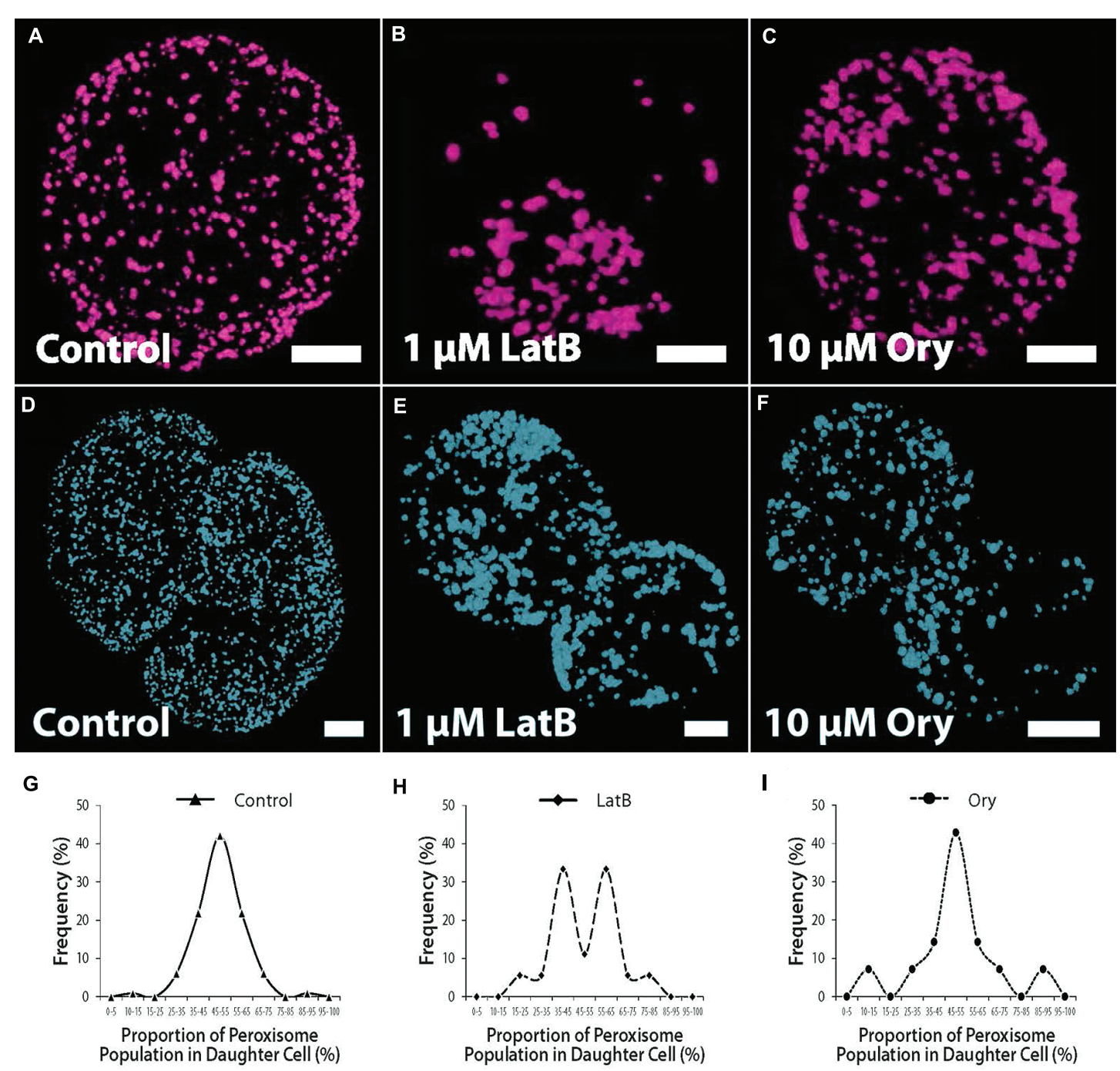

FIGURE 3 | Peroxisome dispersion, inheritance and cytoskeletal inhibitor studies. (A-C) Confocal projection images showing peroxisome distribution in control and inhibitor-treated protoplasts after $72 \mathrm{~h}$ culture.

(A) Uniformly distributed peroxisomes in controls. (B) Clustered and grossly aggregated peroxisomes in LatB-treated cells. (C) Clustering of

peroxisomes, but with fewer tendencies for gross aggregation relative to

LatB-treated cells in Ory-treated cell cultures. (D-F) Peroxisome inheritance in dividing protoplasts. (D) Peroxisome distribution in controls. (E) Peroxisome distribution after LatB-treatment. (F) Peroxisome distribution after Ory-treatment. (G) Controls with proportion of peroxisomes in daughter cells showing small deviation from equal inheritance. (H) LatB-treated and (I) Ory-treated protoplasts showing biased inheritance of protoplasts. Data are from symmetrically divided protoplasts. Bars $=10 \mu \mathrm{m}$. Values are means \pm SEM with $n \geq 100$. breakdown of $\mathrm{H}_{2} \mathrm{O}_{2}$ include enzymes such as APX and CAT. We investigated the expression profile of key peroxisomelocalized gene products involved in ROS metabolism (Figure 6). Peroxisome-localized glutathione-related enzymes, glutathione $S$-transferase 1 (GSTT1) and glutathione reductase (GR1) showed little change in steady-state transcript levels (Figure 6A), as did the monodehydroascorbate (MHA) reducing enzyme MDAR4 and $A P X 3$ (Figure 6B). The levels of MDAR1 transcript did, however, increase significantly over time. The most striking change in expression profile, however, was the more than 10-fold up-regulation of the specific CAT3 isoform of CAT after $96 \mathrm{~h}$ culture (Figure 6C), coincidently, when ROS levels drop most precipitously in Arabidopsis protoplasts (Figure 4B). Levels of a peroxisome-localized copper superoxide dismutase (CSD3) and two other transcripts which code for enzymes associated with other aspects of ROS metabolism were essentially unchanged (Figures 6D,E).

\section{Ascorbate and Glutathione are Abundant and Reduced in Cultured Protoplasts}

To examine in more detail, the redox environment within cultured protoplasts, we profiled whole-cell ascorbate and glutathione levels and oxidation status. During early culture $(0-24 \mathrm{~h})$, when ROS levels are at their peak (Figure 4B), ascorbate and glutathione concentrations remained essentially unchanged (Figures 7A,B). In the next $48 \mathrm{~h}$ of culture, 


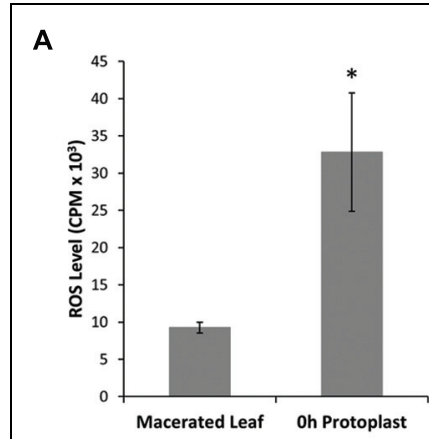

C
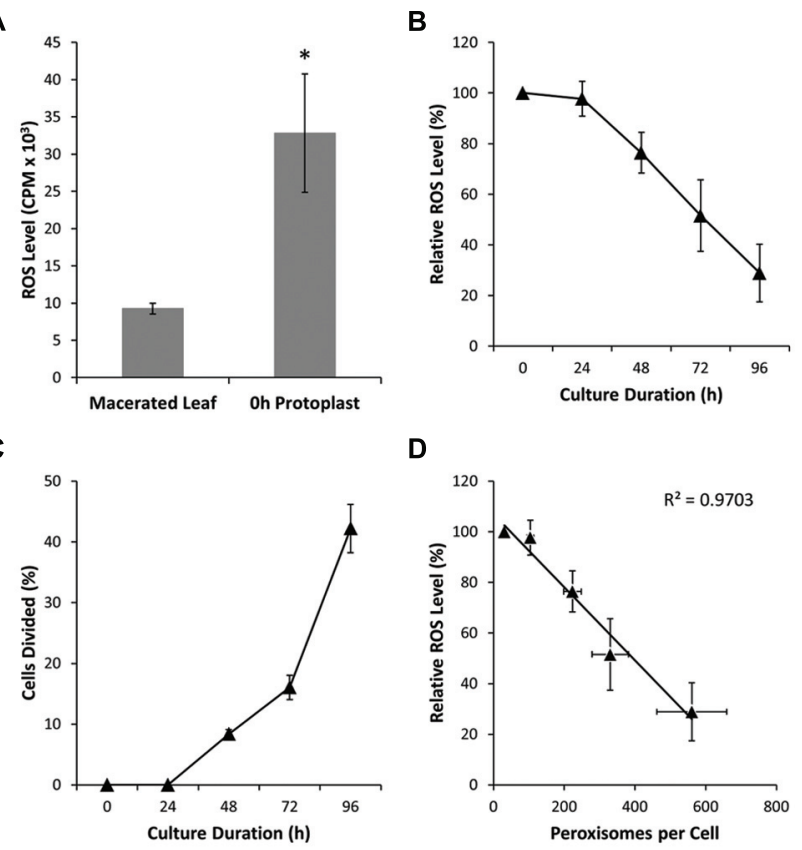

D

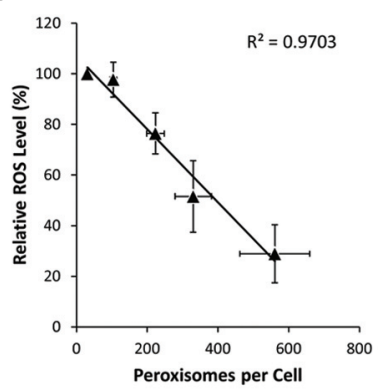

FIGURE 4 | Peroxisome proliferation and ROS detoxification.

(A) Hydrogen peroxide production as measured in macerated leaves (source tissue for protoplast isolation) and in freshly prepared ( 0 h) protoplasts. Note substantial increase in ROS level for fresh protoplasts. (B) Hydrogen peroxide levels in cultured protoplasts decrease during culture and before cellular division. (C) Cell division rate for cultured protoplasts. Cell division occurs after $48 \mathrm{~h}$ culture. (D) Correlation between peroxisome number and ROS level $\left(R^{2}=0.97\right)$. Values are means \pm SEM with $n \geq 3\left({ }^{*} p<0.05\right.$, $t$-test $)$.

however, both ascorbate and glutathione concentrations increased approximately fourfold, after which time, changes in ascorbate and glutathione concentrations stabilized. Moreover, and intriguingly, both antioxidants were maintained in a predominantly reduced state after $24 \mathrm{~h}$ of culture initiation (Figures 7A,B). This surprising finding suggests that either the activity of reductive enzymes in the ascorbate-glutathione cycle (see Figure 7E) is maintained in excess of what is required, or alternatively, that ascorbate and glutathione are not acting as 'frontline' antioxidants in the restoration of ROS homeostasis in cultured protoplasts.

\section{Restoration Versus Maintenance: Differing Roles for Ascorbate/Glutathione and Catalase}

We therefore examined the activity of two key enzymes of the ascorbate-glutathione cycle; APX and GR. The total cellular activity of APX, which oxidizes ascorbate to dehydroascorbate (see Figure 7E), was consistently low during the first $48 \mathrm{~h}$ of culture, but thereafter, increased linearly to approximately fourfold the activity of freshly isolated protoplasts by the end of culture (Figure 7C). Similarly, total cell activity for GR, an enzyme that reduces glutathione disulphide to glutathione (see Figure 7E), was low during early culture (0-24 h) and then increased linearly to approximately 6.5-fold initial activity by the end of protoplast culture (Figure 7C). The activity
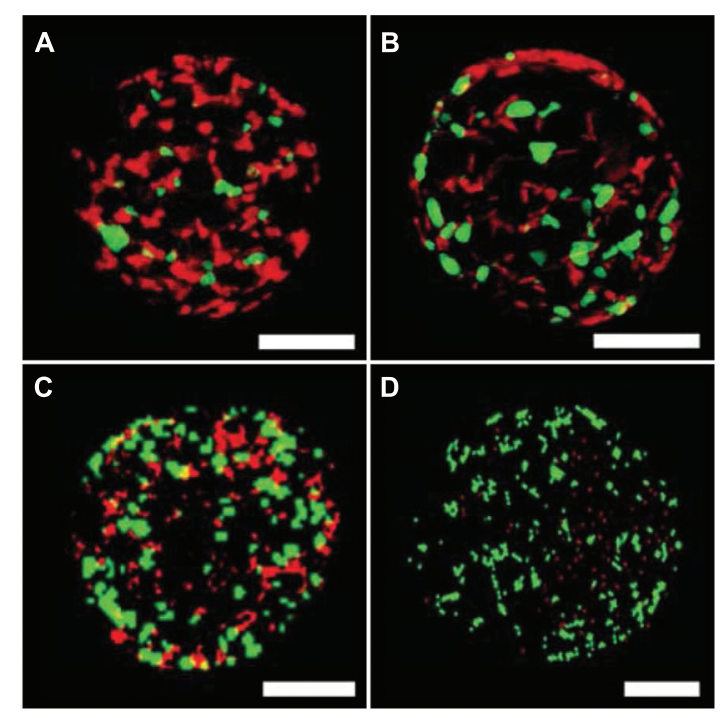

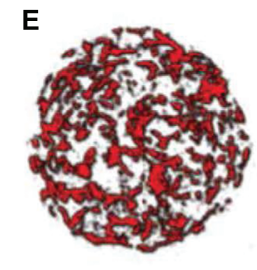

Redox Sensor Red

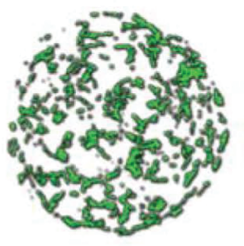

Mitochondrial GFP

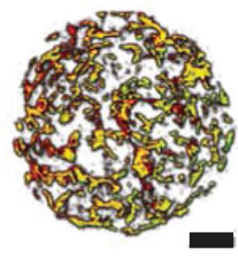

Overlay
FIGURE 5 | Mitochondria expressing GFP labeled with Redox Sensor Red (RSR) show a decrease in number as ROS levels decrease during protoplast culture. (A-D) Confocal projection images of Nicotiana protoplasts incubated for $6 \mathrm{~h}$ in RSR, clockwise from top left; 24, 48, 72, and $96 \mathrm{~h}$. The number of RSR (red) stained mitochondria become fewer as ROS levels decrease (also see Supplementary Figure S4). Green represents GFP-labeled mitochondria with no RSR staining. Bars $=20 \mu \mathrm{m}$ (A-D). (E) Overlay of confocal images of both RSR and GFP (yellow) at the beginning of incubation showing most subcellar ROS arise from the mitochondria. Bars $=10 \mu \mathrm{m}$ (E).

profile for GR correlates well with the levels of reduced glutathione (GSH) measured (Figure 7B) and suggests that the predominance of reduced glutathione may at least in part be attributable to the high activity of GR. However, assuming ROS production in protoplasts is constant or increases during culture, the profile for APX activity does not correlate well with measured ROS levels (compare Figures $\mathbf{4 B}$ and $7 \mathbf{C}$ ), reinforcing the notion that ascorbate is not a 'frontline' antioxidant involved in the restoration of ROS homeostasis in cultured protoplasts.

Finally, we examined CAT, a peroxisome-specific enzyme that reduces $\mathrm{H}_{2} \mathrm{O}_{2}$ to water. CAT activity increased linearly by approximately 2.5 -fold during the first $72 \mathrm{~h}$ of culture and then plateaued (Figure 7D). Interestingly, the theoretical $\mathrm{H}_{2} \mathrm{O}_{2}$ removal capacity conferred by CAT is at least 100 -fold greater than that for APX, throughout culture. Moreover, the plateau in CAT activity (72-96 h) coincided with the plateau or decline 
TABLE 1 | Source of reactive oxygen species (ROS) production in protoplasts as indicated by inhibitors.

\begin{tabular}{|c|c|c|c|}
\hline Inhibitor (Abbreviation) & Concentration & Mechanism of action & $\begin{array}{l}\text { ROS Production } \\
(\%)^{\mathrm{a}}\end{array}$ \\
\hline Control (DMSO) & - & Vehicle for inhibitors & $100 \pm 1.1$ \\
\hline $\begin{array}{l}\text { Diphenyleneiodonium chloride } \\
\text { (DPI) }\end{array}$ & $25 \mu \mathrm{M}$ & General inhibitor of flavoproteins (e.g., NADPH oxidases, mitochondrial complex I) & $22.8 \pm 14.4$ \\
\hline 2-Deoxyglucose (2-DOG) & $2 \mathrm{mM}$ & $\begin{array}{l}\text { Competitive inhibitor of hexokinase. Restricts flux of metabolites through glycolysis } \\
\text { and decreases production of reductants (NADH) }\end{array}$ & $63.4 \pm 2.0$ \\
\hline Allopurinol (AP) & $200 \mu \mathrm{M}$ & Inhibitor of Xanthine Dehydrogenase-Oxidase & $95.5 \pm 10.3$ \\
\hline $\begin{array}{l}\text { Stigmatellin (Stig) } \\
\text { Myxothiazol (Myx) }\end{array}$ & $\begin{array}{l}10 \mu \mathrm{M} \\
10 \mu \mathrm{M}\end{array}$ & $\begin{array}{l}\text { Binds } Q_{0} \text { site of mitochondrial complex III and prevents oxidation of ubiqinone, } \\
\text { stopping mitochondrial electron transport (in the absence of AOX) }\end{array}$ & $\begin{array}{l}29.9 \pm 1.3 \\
34.8 \pm 2.0\end{array}$ \\
\hline $\begin{array}{l}\text { Carbonyl cyanide } \\
\text { 3-chlorophenylhydrazone (CCCP) }\end{array}$ & $0.5 \mu \mathrm{M}$ & $\begin{array}{l}\text { Protonophore. Uncouples mitochondrial electron transport from oxidative } \\
\text { phosphorylation }\end{array}$ & $18.9 \pm 4.3$ \\
\hline
\end{tabular}

a Relative to control cultures. Mean $\pm S E M, n=3$.

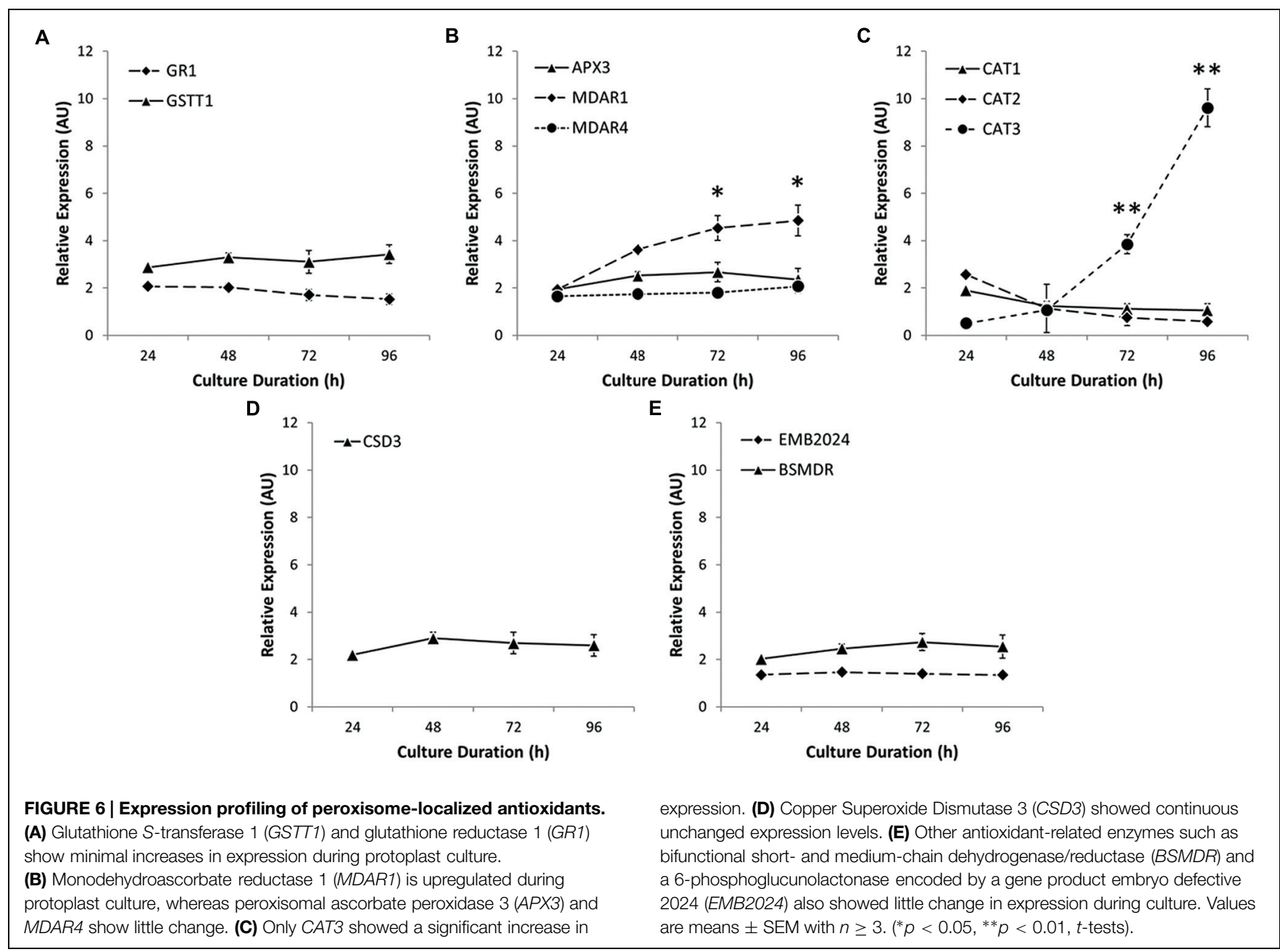

in concentrations of ascorbate and glutathione, respectively (compare Figures 7A,B,D). Taken together, our data suggest that ascorbate and glutathione play a subservient role to CAT in the restoration of ROS homeostasis following the woundinduced oxidative burst in protoplasts, whereas ascorbate and glutathione may play an important role in the maintenance of ROS homeostasis, once it is attained.

\section{Catalase and the Restoration of ROS} Homeostasis During Protoplast Culture is Required for Optimal Regeneration Capability During Protoplast Culture

To confirm the importance of CAT to the restoration of ROS homeostasis, we treated protoplasts with the CAT inhibitor 3-amino-1,2,4-triazole (3-AT, $10 \mathrm{mM}$; (Margoliash 
A

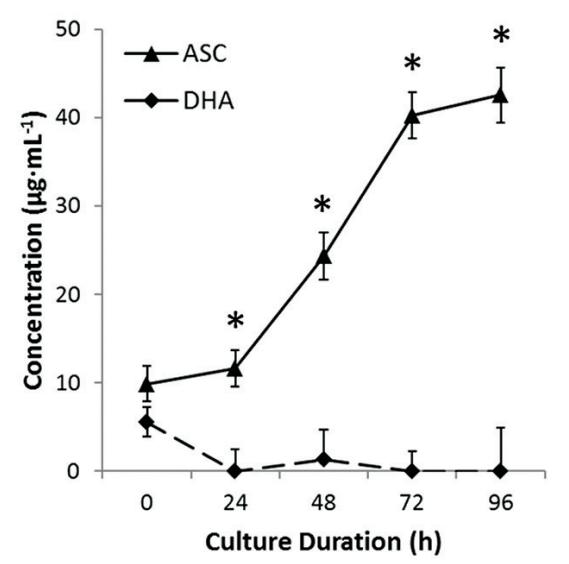

C

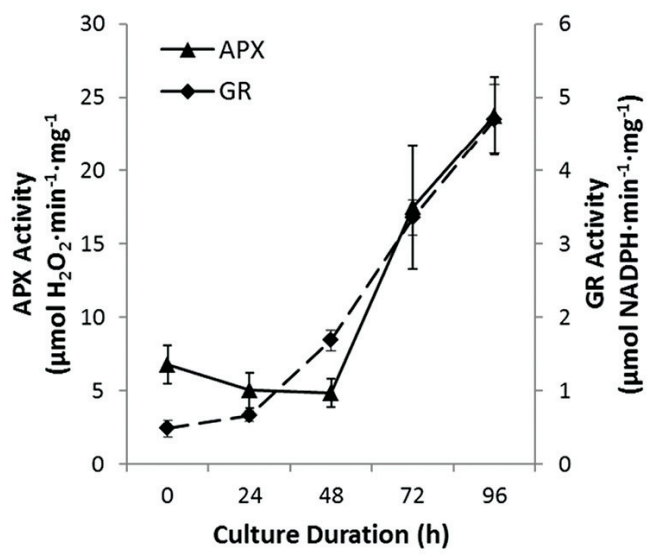

B

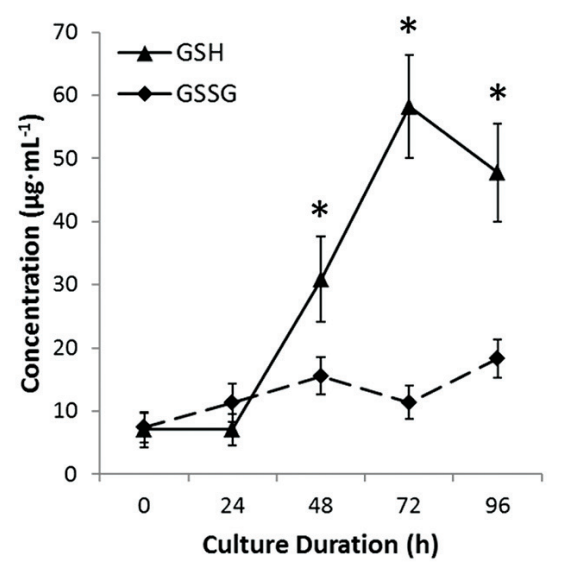

D

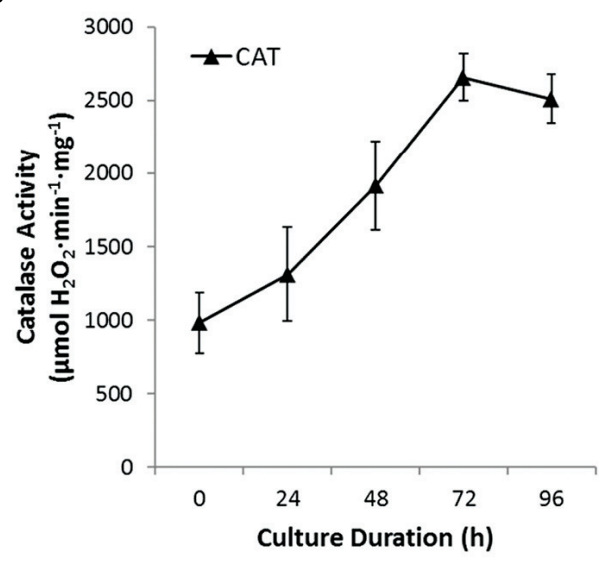

E

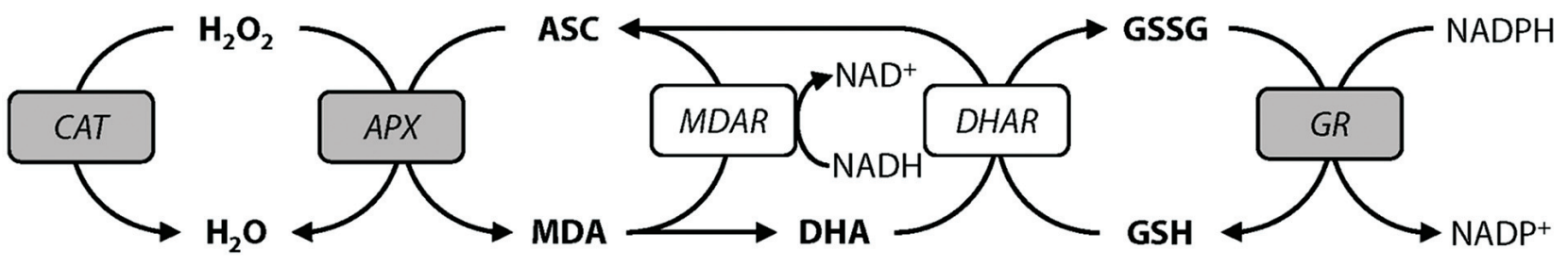

FIGURE 7|Peroxisomes promote ROS homeostasis. (A,B) Quantifying levels of reduced and oxidized ascorbate (A) or reduced and oxidized glutathione (B) revealed that both antioxidants are maintained in a reduced state and that the concentration of both molecules increased during culture. (C) Activity of ascorbate peroxidase (APX) and glutathione reductase (GR) in cultured protoplasts increased steadily after $48 \mathrm{~h}$ culture. (D) The activity of catalase increased through the early phase of culture. Note that the activity of catalase was at least 50 -fold greater than that of maximum APX activity (E) Schematic summary of the key antioxidant cycles in peroxisomes. Enzymes assayed shown in gray. Abbreviation used are: APX, ascorbate peroxidase; ASC, ascorbate; CAT, catalase; DHA, dehydroascorbate; DHAR, dehydroascorbate reductase; GR, glutathione reductase; GSH, glutathione (reduced); GSSG, glutathione disulphide; MDA, monodehydroascorbate; MDAR, monodehydroascorbate reductase. $\mathrm{NADH} / \mathrm{NAD}^{+}$, nicotinamide adenine dinucleotide (reduced/oxidized); $\mathrm{NADPH} / \mathrm{NADP}^{+}$, nicotinamide adenine dinucleotide phosphate (reduced/oxidized). Values are means \pm SEM with $n \geq 3$. (* $p<0.05$, t-test). and Novogrodsky, 1958; Jannat et al., 2011) for $24 \mathrm{~h}$ and examined $\mathrm{H}_{2} \mathrm{O}_{2}$ levels. Protoplast cells treated with 3AT maintained ROS generation at a consistently high level throughout culture (Figure 8A). However, similar treatment of cells with buthionine sulfoximine $(2 \mathrm{mM})$, an inhibitor of the $\gamma$-glutamylcysteine synthase enzyme required for glutathione biosynthesis, had no influence $(3.6 \pm 8.6 \%)$ on the measured levels of $\mathrm{H}_{2} \mathrm{O}_{2}$. Additional evidence for the importance of CAT comes from the cat3 mutant, where increased ROS levels of approximately 50\% $(n \geq 5)$ were observed in cat3 mutant protoplasts compared to WT protoplasts after $96 \mathrm{~h}$ culture (Figure 8B).

To further investigate the influence of peroxisomes and redox balance on plant cell regeneration during protoplast culture, homozygous mutant protoplasts of PEX11a and CAT3 were cultured in parallel with WT protoplasts. Viability of both pex11a 

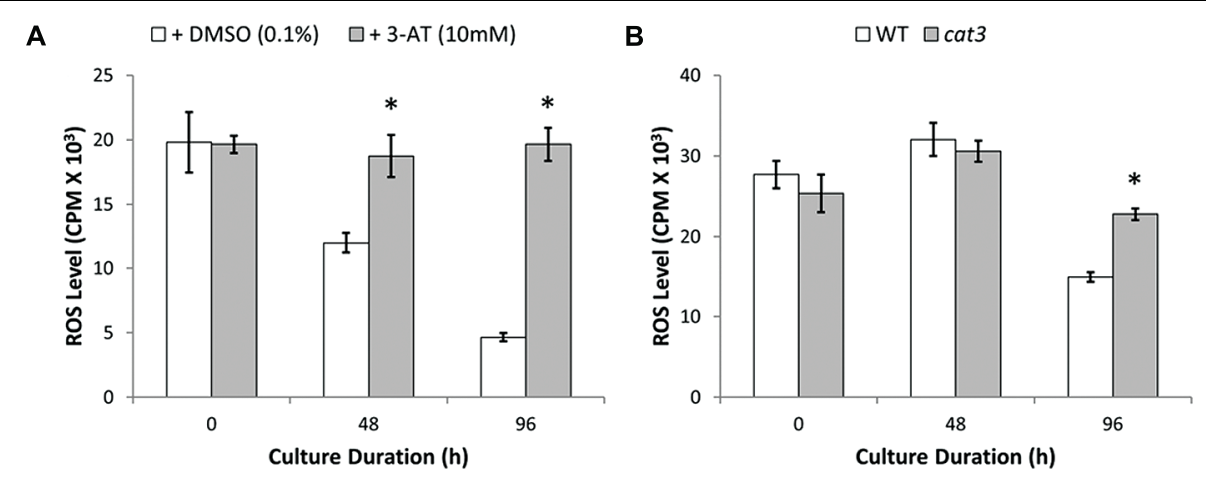

FIGURE 8 | Elevated ROS levels observed in catalase inhibited protoplasts with 3-AT and cat3 mutant protoplast cultures. (A) Increased ROS levels observed throughout culture in catalase inhibited protoplasts treated with 3-AT for $24 \mathrm{~h}$. (B) Homozygous cat3 mutant protoplasts significantly increased ROS levels after $96 \mathrm{~h}$ culture. Values are means \pm SEM with $n \geq 3$. ( ${ }^{*} p<0.05$, $t$-test).

and cat 3 protoplast cultures decreased by approximately $5 \%$ after $96 \mathrm{~h}$ culture (Figures 9A,B). However, after $96 \mathrm{~h}$ culture, reduced cell division rates of approximately 3.5- and 2.5-fold for pex $11 \mathrm{a}$ and cat 3 protoplasts were observed (Figures 9C,D). These data are consistent with a requirement for peroxisomes and CAT and their modulation of redox homeostasis for the initiation of cell division in cultured protoplasts.

\section{Discussion}

\section{Peroxisome Dynamics and AF-Dependent Inheritance in Cells Reprogrammed to Divide}

The large proliferation of peroxisomes and their uniform distribution throughout the cell prior to cell division is the main contributor to their partitioning with minimal bias to daughter cells. These changes that promote unbiased inheritance suggest that it is advantageous to ensure the presence of peroxisomes in nascent daughter cells. This would still be the case even if plant protoplasts were capable of de novo peroxisome biogenesis, a possibility suggested by studies in yeast (Nagotu et al., 2010), but with no evidence in plants (Hu et al., 2012).

Disruption of AFs, and to a lesser extent MTs, perturbed the dispersion of peroxisomes, leading to their aggregation and increased segregation bias. In plant cells, peroxisome motility depends on both AFs and myosin (Mathur et al., 2002; Avisar et al., 2008) supporting the inability of peroxisomes to redistribute uniformly in the cytoplasm of LatB-treated protoplasts. MTs, however, also appeared to have a role, albeit minor, in peroxisome dispersion. In animal cells, where peroxisome motility is predominantly MT dependent, AFs seem to play a cooperative role in peroxisome motility (Rapp et al., 1996). Mitochondrial motility in plants is also AF-dependent, yet their positioning within the cell is regulated by both MTs and AFs (Van Gestel et al., 2002). Therefore potentially, MTs may play similar roles in peroxisome motility and positioning. The action of oryzalin on nucleus positioning and cytokinesis, in our protoplast system, is consistent with MT inhibition (Sheahan et al., 2004). However, while the oryzalin pharmacological observations point to a limited role of MTs in peroxisome dispersion, detailed studies of MT dynamics are required.

\section{Peroxisome Dynamics During Dedifferentiation and Division Induction Compared to other Organelles}

The increase in peroxisome numbers, their uniform dispersion throughout the cytoplasm followed by unbiased inheritance to daughter cells is similar to what occurs with mitochondria (Sheahan et al., 2004). The mitochondria do undergo massive fusion (Sheahan et al., 2005) prior to fission, but the cytoskeletal dependent dispersal prior to division is similar to peroxisomes. Though AF dependent movement of peroxisomes is known (Wada and Suetsugu, 2004) the cytoskeleton inhibitor analysis indicates that it is the AFs that are primarily responsible for the uniform dispersion and this enables the unbiased partitioning. What occurs with the chloroplasts is, however, quite different. Chloroplasts, possibly because they are much larger than mitochondria and peroxisomes, are reproducibly translocated from the protoplast cortex to the perinuclear region (see Sheahan et al., 2004 with supplementary video) to achieve unbiased partitioning. The perinuclear clustering appears to be driven by a process involving a dynamic re-organization of the actin network followed by entrapment adjacent to the nucleus (Sheahan et al., 2004; Figure 1A). In differentiated cells such as the leaf mesophyll cells there are well established associations of peroxisomes and chloroplasts (Schumann et al., 2007; Figure 1B) and they distribute together (Wada and Suetsugu, 2004).

The chloroplasts do not divide as they dedifferentiate to proplastids before division; plastid division occurring from the 4 cell stage (Thomas and Rose, 1983). What is clear is that the pathway to totipotency is highly ordered with the cytoskeleton ensuring the unbiased inheritance of the organelles.

\section{Integrating Organelle Inheritance Processes with Cell Growth, the Cell Cycle and the Cytoskeleton}

The mechanisms by which information about cell volume is conveyed to cell cycle regulators remains poorly understood 


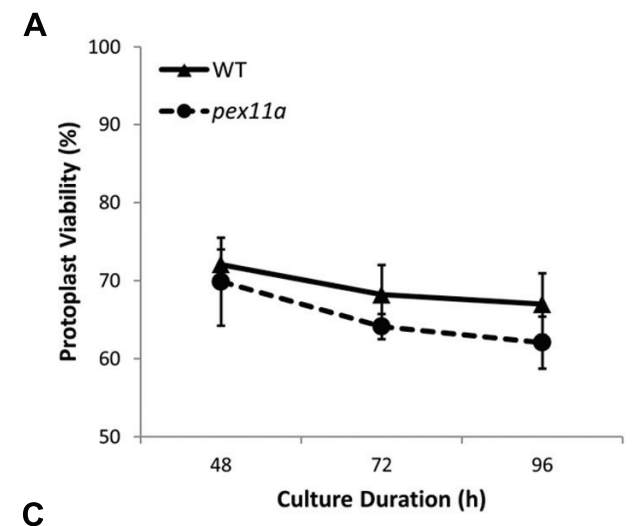

C

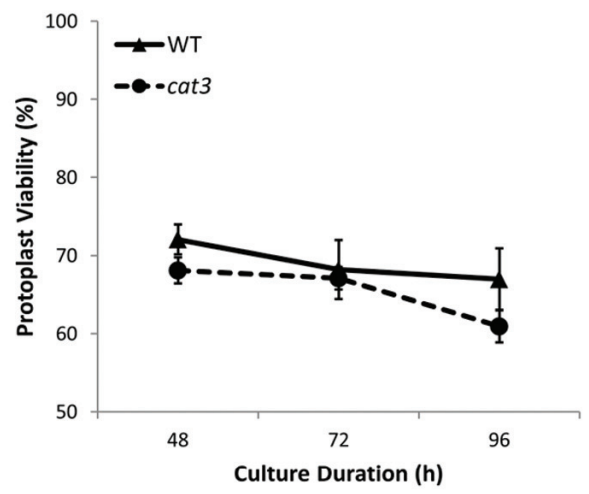

FIGURE 9 | Mutants of both PEX11a and CAT3 protoplast cultures exhibited reduced cell division rates. (A,B) Viability of pex11a and cat3 protoplast cultures decreased by approximately $5 \%$ compared to WT cultures
B
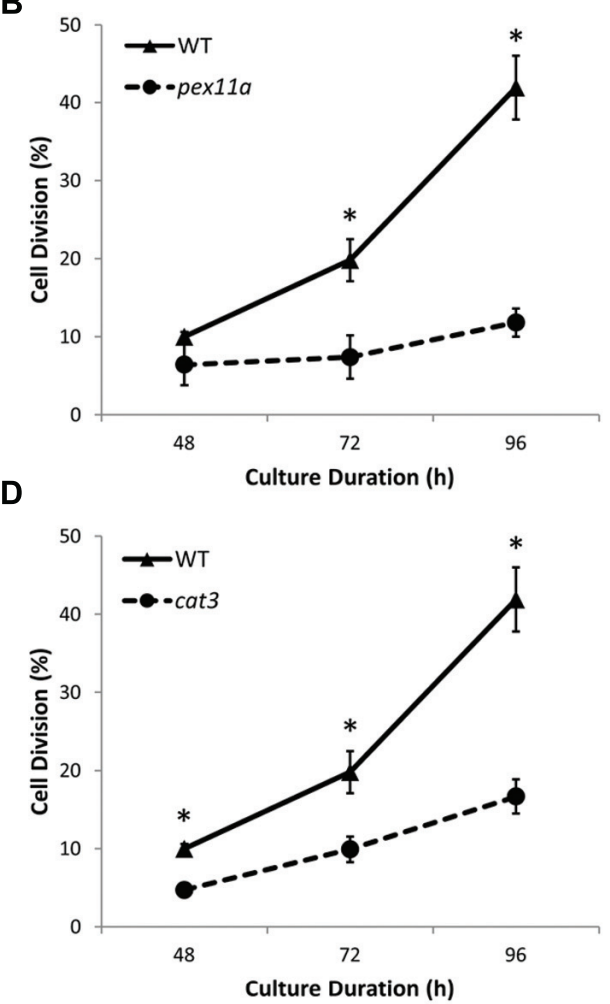

over 96 h. (C,D) A delayed cell division initiation with reduced cell division rates by approximately 3.5 - and 2.5 -fold for pex $11 \mathrm{a}$ and cat3 cultures respectively after $96 \mathrm{~h}$. Values are means \pm SEM with $n \geq 3$. ( ${ }^{*} p<0.05, t$-test).
(Jorgensen et al., 2002). Disruption of AFs or MTs does not appear to have a large effect on cell expansion in cultured protoplasts, however, numbers of mitochondria (Sheahan et al., 2004) and peroxisomes (Supplementary Figure S5) are consistently lower in cytoskeletal inhibitor-treated cells compared to controls. Other mechanisms, such as those involving redox homeostasis (Foyer and Noctor, 2005), independent of cell volume signaling, are also likely to influence peroxisome dynamics and cell cycle progression in protoplasts.

\section{Redox, Dedifferentiation and Cell Division Induction}

A very rapid oxidative burst is an important stress signal in isolated plant cells or tissue which is likely part of the signaling, in conjunction with plant hormones in the medium that leads to cell division induction and plant regeneration (Pasternak et al., 2002; Wang et al., 2011; Rose et al., 2013). The importance of ROS in signaling at both local and systemic levels, with plant hormone webs, is now widely recognized (Mittler et al., 2011). High ROS levels for prolonged periods can of course be highly damaging to cellular components (Foyer and Noctor, 2011), however, regulating ROS levels after ROS bursts necessitates suitable homeostatic mechanisms for cell metabolism and development requirements.
The oxidative burst that accompanies protoplast isolation and early culture corresponds to the period of maximal cellular dedifferentiation (Zhao et al., 2001). Indeed, in animal cells, dedifferentiation $\left(G_{0}\right.$ to $G_{1}$ transition) is regulated by redox controls that converge on cyclin D (Burch and Heintz, 2005), while in plant cells, moderate ROS levels up-regulate cyclin dependent kinase A1 activity and accelerate the cell cycle activation of differentiated leaf cells (Féher et al., 2008). Thus, an oxidative burst in protoplasts appears necessary to transition from $G_{0}$ to $G_{1}$. Although an oxidative burst seems to promote dedifferentiation, a reduced cellular environment is necessary for continued progression through the cell cycle. The status of redox couples in the cell connects environmental signals to the regulation of cell division, by controlling progression through the $G_{1}$ to $S$ phase checkpoint (Reichheld et al., 1999; Foyer and Noctor, 2005). Two of the most important redox couples in plant cells are the ascorbate-dehydroascorbate [ASC/DHA] and glutathione-glutathione disulphide [GSH/GSSG] couples, with direct evidence for both redox couples influencing the transition from $\mathrm{G}_{1}$ to $\mathrm{S}$ phase in plant cells (Liso et al., 1988; CordobaPedregosa et al., 1996; Potters et al., 2000, 2004). Our findings that glutathione and ascorbate were predominantly reduced and abundant, shortly after the initiation of protoplast culture, suggests that the redox-signaling environment in cultured protoplasts is primed for progression through the cell cycle. This 
is in contrast to the slowly dividing cells of the root quiescent center, where ascorbate and glutathione are maintained at low levels and in a primarily oxidized form (Kerk and Feldman, 1995; Sanchez-Fernandez et al., 1997). The fact that ascorbate and glutathione were present in the reduced state, also implies that either the cellular machinery that recycles the oxidized forms of these antioxidants is highly active or alternatively, that these molecules do not participate in frontline ROS detoxification. The increasing expression of MDAR (specifically MDAR1) involved in the reduction of MHA coupled with the relatively unchanging expression of GSSG (GR1) and the low total activity of GR in protoplasts (maximum activity was $\sim 0.005 \mu \mathrm{mol} \cdot \mathrm{min}^{-1} \cdot \mu \mathrm{g}^{-1}$ of cells at $96 \mathrm{~h}$ ) relative to the total concentration of glutathione $\left(\sim 0.35 \mu \mathrm{mol} \cdot \mu \mathrm{g}^{-1}\right.$ of cells at $\left.96 \mathrm{~h}\right)$ suggests that the latter alternative is more likely.

\section{Changes in Peroxisome Proliferation and Peroxisome-Localizsed Antioxidants in Relation to Cell Division Induction}

There is a very large increase in peroxisome numbers and total peroxisome volume associated with the protoplast culture prior to the first cell division. Consistent with the increased peroxisome numbers and volume, transcript levels of most peroxisome genes involved in biogenesis and proliferation were upregulated during early protoplast culture (Supplementary Figure S1). This increased peroxisome number contributes to an increased antioxidant capacity with the increased numbers tightly inversely correlated with ROS levels. In cultured suspension cells there is only one regular doubling of peroxisomes at each cell cycle (Lingard et al., 2008). This may also be the case for dividing cells of the meristems in plants.

Peroxisomes participate in a variety of processes related to oxidative metabolism, and the expression of genes for peroxisome-localized antioxidants is influenced by both metabolic and environmental cues (León, 2008; Palma et al., 2009). Peroxisomes generate ROS, but can also rescue cells from the damaging effects of ROS. Accordingly, peroxisomes are the main site for renewal of cellular antioxidants and house an arsenal of antioxidant enzymes; they are also the sole location of the cells principal $\mathrm{H}_{2} \mathrm{O}_{2}$-degrading enzyme, CAT (Lopez-Huertas et al., 2000; Corpas et al., 2001). Total CAT activity and CAT3 (but not CAT1 or CAT2) gene expression increased during culture (Figure 6C). Interestingly, CAT3 is also upregulated in response to oxidative stress in senescing tissues in Arabidopsis (Du et al., 2008). The other peroxisome-localized gene directly involved in the detoxification of ROS is APX3. However, the rate of increase in $A P X 3$ expression after $48 \mathrm{~h}$ protoplast culture, when ROS levels decline most precipitously (Figure 4B) was only $62 \%$ of that for CAT3 (Figures 6B,C). Moreover, the $\mathrm{K}_{\mathrm{cat}} / \mathrm{K}_{\mathrm{m}}$ values for plant CAT, which are in the range of $10^{4}-10^{5} \mathrm{~s}^{-1} \cdot \mu \mathrm{M}^{-1}$ (Havir and McHale, 1990), dwarf those of APX at around $10^{-1}-10^{0}$ $s^{-1} \cdot \mu M^{-1}$ (Lad et al., 2002). Because of a low affinity $\left(K_{m}\right)$ for $\mathrm{H}_{2} \mathrm{O}_{2}$, but high turnover rate $\left(\mathrm{K}_{\text {cat }}\right)$, CAT is ideally suited to the removal of large amounts of ROS, as appears to be the case following an oxidative burst.

Peroxisomes respond to ROS generated in other intra- or extracellular locations, probably to protect the cell from excessive oxidative damage (Lopez-Huertas et al., 2000; Schrader and Fahimi, 2006), while over expression of CAT in mice extends their lifespan (Schriner et al., 2005). These data (Figure 7) suggest peroxisomes, and in particular CAT, play a key role in restoring homeostatic levels of ROS, whereas, ASC/DHA and GSH/GSSG redox couples appear to have a more modulating role as the protoplasts proceed toward cell cycle initiation. Homozygous knockout mutants of PEX11a, which is involved in regulating peroxisome numbers (Lingard and Trelease, 2006; Orth et al., 2007), and CAT3 cause reduced cell division. This is consistent with peroxisomes having an important role in the restoration of ROS levels after the oxidative burst, establishing an optimum subcellular redox environment for plant cell cultures acquiring totipotency.

\section{Peroxisome Dynamics: Dual Functions in Inheritance and Redox Homeostasis?}

The uniform dispersion of peroxisomes throughout the cytoplasm ensures unbiased partitioning of these now small and numerous organelles and facilitates peroxisomal functions. Transient clustering of peroxisomes near the developing cell plate in onion cells (Collings et al., 2003) and the classical association of peroxisomes with chloroplasts and mitochondria in photosynthesizing mesophyll cells suggests that peroxisomes do localize to specific sites when required. Interestingly, proteins responsible for peroxisome biogenesis and morphology are induced by ROS, and in both plant and animals cells peroxisomes proliferate in response to stress. Indeed, a number of studies in plants link peroxisome proliferation with stresses that perturb ROS homeostasis (Chang et al., 1999; Lopez-Huertas et al., 2000; del Rio et al., 2006). Whether peroxisomes proliferate simply because of stress, or instead, to enhance peroxisomal activities that protect against oxidative stress, is still unclear. However, the latter is consistent with the cellular physiology. The findings of this study and our previous work (Sheahan et al., 2004, 2007b) indicate that plant organelles use diverse partitioning strategies to ensure unbiased inheritance at cell division. These strategies, however, presumably evolved within the constraints of maintaining cellular function, such as modulating the redox environment during morphogenic responses to stress (Potters et al., 2007), a key factor facilitating totipotency in plants.

\section{Acknowledgments}

We thank Maureen Hanson (Cornell University) for kindly providing coxIV-GFP tobacco seed and David Logan (Université d'Angers) for mGFP5-atpase Arabidopsis seed. This research was supported by an Australian Research Council (ARC) Grant (CEO348212) to RR, by an ARC Australian Postdoctoral Fellowship (DP0770679) to MS and The University of Newcastle Priority Research Centre for Chemical Biology.

\section{Supplementary Material}

The Supplementary Material for this article can be found online at: http://journal.frontiersin.org/article/10.3389/fpls.2015.00658 


\section{References}

Avisar, D., Prokhnevsky, A. I., Makarova, K. S., Koonin, E. V., and Dolja, V. V. (2008). Myosin XI-K Is required for rapid trafficking of golgi stacks, peroxisomes, and mitochondria in leaf cells of Nicotiana benthamiana. Plant Physiol. 146, 1098-1108. doi: 10.1104/pp.107.113647

Baker, A., and Graham, I. A. (2002). Plant Peroxisomes: Biochemistry, Cell Biology and Biotechnological Applications. Dordrecht: Kluwer Academic Publishers.

Beevers, H. (1979). Microbodies in higher plants. Annu. Rev. Plant Physiol. 30, 159-193. doi: 10.1146/annurev.pp30.060179.001111

Burch, P. M., and Heintz, N. H. (2005). Redox regulation of cell-cycle reentry: cyclin D1 as a primary target for the mitogenic effects of reactive oxygen and nitrogen species. Antioxid. Redox Signal. 7, 741-751. doi: 10.1089/ars.2005.7.741

Chang, C.-C., South, S., Warren, D., Jones, J., Moser, A. B., Moser, H. W., et al. (1999). Metabolic control of peroxisome abundance. J. Cell Sci. 112, 1579-1590.

Chupeau, M.-C., Granier, F., Pichon, O., Renou, J.-P., Gaudin, V., and Chupeau, Y. (2013). Characterization of the early events leading to totipotency in an Arabidopsis protoplast liquid culture by temporal transcript profiling. Plant Cell 25, 2444-2463. doi: 10.1105/tpc.113.109538

Collings, D. A., Harper, J. D. I., and Vaughn, K. C. (2003). The association of peroxisomes with the developing cell plate in dividing onion root cells depends on actin microfilaments and myosin. Planta 218, 204-216. doi: 10.1007/s00425003-1096-2

Cordoba-Pedregosa, M. D. C., Gonzalez-Reyes, J. A., Canadillas, M. D. C., Navas, P., and Cordoba, F. (1996). Role of apoplastic and cell-wall peroxidases on the stimulation of root elongation by ascorbate. Plant Physiol. 112, 11191125. doi: 10.1104/pp.112.3.1127

Corpas, F. J., Barroso, J. B., and del Rio, L. A. (2001). Peroxisomes as a source of reactive oxygen species and nitric oxide signal molecules in plant cells. Trends Plant Sci. 6, 145-150. doi: 10.1016/S1360-1385(01)01898-2

Curtis, M. D., and Grossniklaus, U. (2003). A gateway cloning vector set for highthroughput functional analysis of genes in planta. Plant Physiol. 133, 462-469. doi: 10.1104/pp.103.027979

Cutler, A., Saleem, M., and Wang, H. (1991). Cereal protoplast recalcitrance. In Vitro Cell. Dev. Biol. Plant 27, 104-111. doi: 10.1007/BF026 32192

Cutler, S. R., Ehrhardt, D. W., Griffitts, J. S., and Somerville, C. R. (2000). Random GFP::cDNA fusions enable visualization of subcellular structures in cells of Arabidopsis at a high frequency. Proc. Natl. Acad. Sci. U.S.A. 97, 3718-3723. doi: 10.1073/pnas97.7.3178

del Rio, L. A., Sandalio, L. M., Corpas, F. J., Palma, J. M., and Barroso, J. B. (2006). Reactive oxygen species and reactive nitrogen species in peroxisomes. Production, scavenging, and role in cell signaling. Plant Physiol. 141, 330-335. doi: 10.1104/pp.106.078204

Du, Y.-Y., Wang, P.-C., Chen, J., and Song, C.-P. (2008). Comprehensive functional analysis of the catalase gene family in Arabidopsis thaliana. J. Int. Plant Biol. 50, 1318-1326. doi: 10.1111/j.1744-7909.2008.00741.x

Eubel, H., Meyer, E. H., Taylor, N. L., Bussell, J. D., O’Toole, N., Heazlewood, J. L., et al. (2008). Novel proteins, putative membrane transporters, and an integrated metabolic network are revealed by quantitative proteomic analysis of Arabidopsis cell culture peroxisomes. Plant Physiol. 148, 1809-1829. doi: 10.1104/pp.108.129999

Faltin, Z., Holland, D., Velcheva, M., Tsapovetsky, M., Roeckel-Drevet, P., Handa, A. K., et al. (2010). Glutathione peroxidase regulation of reactive oxygen species level is crucial for in vitro plant differentiation. Plant Cell Physiol. 51, 1151-1162. doi: 10.1093/pcp/pcq082

Féher, A., Ötvös, K., Pasternak, T. P., and Pettkó-Szandtner, A. (2008). The involvement of reactive oxygen species (ROS) in the cell cycle activation (G0-to-G1 transition) of plant cells. Plant Signal. Behav. 3, 823-826. doi: $10.4161 /$ psb.3.10.5908

Foyer, C. H., and Noctor, G. (2005). Redox homeostasis and antioxidant signaling: a metabolic interface between stress perception and physiological responses. Plant Cell 17, 1866-1875. doi: 10.1105/tpc.105.033589

Foyer, C. H., and Noctor, G. (2011). Ascorbate and glutathione: the heart of the redox hub. Plant Physiol. 155, 2-18. doi: 10.1104/pp.110.167569

Franklin, A. E., and Cande, W. Z. (1999). Nuclear organization and chromosome segregation. Plant Cell 11, 523-534. doi: 10.1105/tpc.11.4.523
Griffith, O. W. (1985). "Glutathione and glutathione disulphide," in Methods of Enzymatic Analysis, ed. H. U. Bergmeyer (Weinheim: Verlagsgesellschaft $\mathrm{mbH}), 521-529$.

Havir, E. A., and McHale, N. A. (1990). Purification and characterization of an isozyme of catalase with enhanced-peroxidatic activity from leaves of Nicotiana sylvestris. Arch. Biochem. Biophys. 283, 491-495. doi: 10.1016/00039861(90)90672-L

Hayashi, M., and Nishimura, M. (2003). Entering a new era of research on plant peroxisomes. Curr. Opin. Plant Biol. 6, 577-582. doi: 10.1016/j.pbi.2003.09.012

Hayashi, M., Toriyama, K., Kondo, M., Kato, A., Mano, S., De Bellis, L., et al. (2000). Functional transformation of plant peroxisomes. Cell Biochem. Biophys. 32, 295-304.

Horsch, R. B., Fry, J. E., Hoffmann, N. L., Eichholtz, D., Rogers, S. G., and Fraley, R. T. (1985). A simple and general method for transferring genes into plants. Science 227, 1229-1231. doi: 10.1126/science.227.4691.1229

Hu, J., Baker, A., Bartel, B., Linka, N., Mullen, R. T., Reumann, S., et al. (2012). Plant peroxisomes: biogenesis and function. Plant Cell 24, 2279-2303. doi: 10.1105/tpc.112.096586

Jannat, R., Uraji, M., Morofuji, M., Hossain, M. A., Islam, M. M., Nakamura, Y., et al. (2011). The roles of CATALASE2 in abscisic acid signaling in Arabidopsis guard cells. Biosci. Biotechnol. Biochem. 75, 2034-2036. doi: 10.1271/bbb.110344

Johnson, T. L., and Olsen, L. J. (2001). Building new models for peroxisome biogenesis. Plant Physiol. 127, 731-739. doi: 10.1104/pp. 010262

Jorgensen, P., Nishikawa, J. L., Breitkreutz, B.-J., and Tyers, M. (2002). Systematic identification of pathways that couple cell growth and division in yeast. Science 297, 395-400. doi: 10.1126/science. 1070850

Kao, K. N., and Michayluk, M. R. (1975). Nutritional requirements for growth of Vicia hajastana cells and protoplasts at a very low population density in liquid media. Planta 126, 105-110. doi: 10.1007/BF00380613

Kaur, N., and $\mathrm{Hu}$, J. (2009). Dynamics of peroxisome abundance: a tale of division and proliferation. Curr. Opin. Plant Biol. 12, 781-788. doi: 10.1016/jpbi.2009.08.001

Kerk, N. M., and Feldman, N. J. (1995). A biochemical model for the initiation and maintenance of the quiescent center: implications for organization of root meristems. Development 121, 2825-2833.

Köhler, R. H., Zipfel, W. R., Webb, W. W., and Hanson, M. R. (1997). The green fluorescent protein as a marker to visualize plant mitochondria in vivo. Plant $J$. 11, 613-621. doi: 10.1046/j.1365-313X.1997.11030613.x

Lad, L., Mewies, M., and Raven, E. L. (2002). Substrate binding and catalytic mechanism in ascorbate peroxidase: evidence for two ascorbate binding sites. Biochemistry 41, 13774-13781. doi: 10.1021/bi0261591

Law, M. Y., Charles, S. A., and Halliwell, B. (1983). Glutathione and ascorbic acid in spinach (Spinacia oleracea) chloroplasts. Biochem. J. 210, 899-903. doi: 10.1042/bj2100899

León, J. (2008). Peroxisome proliferation in Arabidopsis: the challenging identification of ligand perception and downstream signaling is closer. Plant Signal. Behav. 3, 671-673. doi: 10.4161/psb.3.9.5780

Leucci, M. R., Di Sansebastiano, G.-P., Gigante, M., Dalessandro, G., and Piro, G. (2007). Secretion marker proteins and cell-wall polysaccharides move through different secretory pathways. Planta 225, 1001-1017. doi: 10.1007/s00425-0060407-9

Li, Y., and Trush, M. A. (1998). Diphenyleneiodonium, an NAD(P)H oxidase inhibitor, also potently inhibits mitochondrial reactive oxygen species production. Biochem. Biophys. Res. Commun. 253, 295-299. doi: 10.1006/bbrc.1998.9729

Lingard, M. J., Gidda, S. K., Bingham, S., Rothstein, S. J., Mullen, R. T., and Trelease, R. N. (2008). Arabidopsis PEROXIN11c-e, FISSION1b, and DYNAMIN-RELATED PROTEIN3A cooperate in cell cycleassociated replication of peroxisomes. Plant Cell 20, 1567-1585. doi: 10.1105/tpc.107.057679

Lingard, M. J., and Trelease, R. N. (2006). Five Arabidopsis peroxin 11 homologs individually promote peroxisome elongation, duplication or aggregation. J. Cell Sci. 119, 1961-1972. doi: 10.1242/cs.02904

Liso, R., Innocenti, A. M., Bitonti, M. B., and Arrigoni, O. (1988). Ascorbic acid-induced progression of quiescent centre cells from G1 to S phase. New Phytol. 110, 469-471. doi: 10.1111/j.1469-8137.1988.tb 00283.x 
Logan, D. C., and Leaver, C. J. (2000). Mitochondria-targeted GFP highlights the heterogeneity of mitochondrial shape, size and movement within living plant cells. J. Exp. Bot. 51, 865-871. doi: 10.1093/jexbot/51.346.865

Lopez-Huertas, E., Charlton, W. L., Johnson, B., Graham, I. A., and Baker, A. (2000). Stress induces peroxisome biogenesis genes. EMBO J. 19, 6770-6777. doi: 10.1093/emboj/19.24.6770

Margoliash, E., and Novogrodsky, A. (1958). A study of the inhibition of catalase by 3-amino-1:2:4:-triazole. Biochem. J. 68, 468-475. doi: 10.1042/bj0680468

Maruthasalam, S., Liu, Y. L., Sun, C. M., Chen, P. Y., Yu, C. W., Lee, P. F., et al. (2010). Constitutive expression of a fungal glucose oxidase gene in transgenic tobacco confers chilling tolerance through the activation of antioxidative defence system. Plant Cell Rep. 29, 1035-1048. doi: 10.1007/s00299-010-0889-6

Mathur, J., Mathur, N., and Hulskamp, M. (2002). Simultaneous visualization of peroxisomes and cytoskeletal elements reveals actin and not microtubulebased peroxisome motility in plants. Plant Physiol. 128, 1031-1045. doi: 10.1104/pp.011018

Mittler, R., Vanderauwera, S., Suzuki, N., Miller, G., Tognetti, V. B., Vandepoele, K., et al. (2011). ROS signaling: the new wave? Trends Plant Sci. 16, 300-309. doi: 10.1016/j.tplants.2011.03.007

Murashige, T., and Skoog, F. (1962). A revised medium for rapid growth and bio assays with tobacco tissue cultures. Physiol. Plant 15, 473-497. doi: 10.1111/j.1399-3054.1962.tb08052.x

Murphy, T. M., and Huerta, A. J. (1990). Hydrogen peroxide formation in cultured rose cells in response to UV-C radiation. Physiol. Plant 78, 247-253. doi: 10.1111/j.1399-3054.1990.tbo02088.x

Nagotu, S., Veenhuis, M., and van der Klei, I. J. (2010). Divide et impera: the dictum of peroxisomes. Traffic 11, 175-184. doi: 10.1111/j.16000-0854.2009.01019.x

Nyathi, Y., and Baker, A. (2006). Plant peroxisomes as a source of signalling molecules. Biochim. Biophys. Acta 1763, 1478-1495. doi: 10.1016/j.bbamcr.2006.08.031

Orth, T., Reumann, S., Zhang, X., Fan, J., Wenzel, D., Quan, S., et al. (2007). The PEROXIN11 protein family controls peroxisome proliferation in Arabidopsis. Plant Cell 19, 333-350. doi: 10.1105/tpc.106.045831

Palma, J. M., Corpas, F. J., and del Rio, L. A. (2009). Proteome of plant peroxisomes: new perspectives on the role of these organelles in cell biology. Proteomics 9 , 2301-2312. doi: 10.1002/pmic.200700732

Papadakis, A. K., and Roubelakis-Angelakis, K. A. (1999). The generation of active oxygen species differs in tobacco and grapevine mesophyll protoplasts. Plant Physiol. 121, 197-206. doi: 10.1104/pp.121.1.1.197

Papadakis, A. K., Siminis, C. I., and Roubelakis-Angelakis, K. A. (2001). Reduced activity of antioxidant machinery is correlated with suppression of totipotency in plant protoplasts. Plant Physiol. 126, 434-444. doi: 10.1104/pp.12 6.1 .434

Pasternak, T. P., Prinsen, E., Ayaydin, F., Miskolczi, P., Potters, G., Asard, H., et al. (2002). The Role of auxin, pH, and stress in the activation of embryogenic cell division in leaf protoplast-derived cells of alfalfa. Plant Physiol. 129, 1807-1819. doi: 10.1104/pp.000810

Petřivalský, M., Vaníčková, P., Ryzí, M., Navrátilová, B., Piterková, J., Sedlářová, M., et al. (2012). The effects of reactive nitrogen and oxygen species on the regeneration and growth of cucumber cells from isolated protoplasts. Plant Cell Tiss. Organ Cult. 108, 237-249. doi: 10.1007/s11240-011-0035.3

Pfaffl, M. W. (2001). A new mathematical model for relative quantification in real-time RT-PCR. Nucleic Acids Res. 29, e45. doi: 10.1093/nar/29.9.e45

Potrykus, I., and Shillito, R. D. (1986). Protoplasts: isolation, culture and regeneration. Methods Enzymol. 118, 549-578. doi: 10.1016/00766879(86)18101-8

Potters, G., Horemans, N., Bellone, S., Caubergs, R. J., Trost, P., Guisez, Y., et al. (2004). Dehydroascorbate influences the plant cell cycle through a glutathione-independent reduction mechanism. Plant Physiol. 134, 1479-1487. doi: $10.1104 /$ pp.103.033548

Potters, G., Horemans, N., Caubergs, R. J., and Asard, H. (2000). Ascorbate and dehydroascorbate influence cell cycle progression in a tobacco cell suspension. Plant Physiol. 124, 17-20. doi: 10.1104/pp.124.1.17

Potters, G., Pasternak, T. P., Guisez, Y., Palme, K. J., and Jansen, M. A. (2007). Stress-induced morphogenic responses: growing out of trouble? Trends Plant Sci. 12, 98-105. doi: 10.1016/j.tplants.2007.01.004

Pracharoenwattana, I., and Smith, S. M. (2008). When is a peroxisome not a peroxisome? Trends Plant Sci. 13, 522-525. doi: 10.1016/j.tplants.2008.07.003
Ramakers, C., Ruijter, J. M., Deprez, R. H., and Moorman, A. F. (2003). Assumption-free analysis of quantitative real-time polymerase chain reaction (PCR) data. Neurosci. Lett. 339, 62-66. doi: 10.1016/S0304-3940(02)01423-4

Rapp, S., Saffrich, R., Anton, M., Jakle, U., Ansorge, W., Gorgas, K., et al. (1996). Microtubule-based peroxisome movement. J. Cell Sci. 109, 837-849.

Reichheld, J.-P., Vernoux, T., Lardon, F., Van Montagu, M., and Inzé, D. (1999). Specific checkpoints regulate plant cell cycle progression in response to oxidative stress. Plant J. 17, 647-656. doi: 10.1046/j.1365-313X.1999.00413.x

Riganti, C., Gazzano, E., Polimeni, M., Costamagna, C., Bosia, A., and Ghigo, D. (2004). Diphenyleneiodonium inhibits the cell redox metabolism and induces oxidative stress. J. Biol. Chem. 279, 47726-47731. doi: 10.1074/jbc.M406314200

Rose, R. J., Sheahan, M. B., and Tiew, T. W.-Y. (2013). "Connecting stress to development in the induction of somatic embryogenesis," in Somatic Embryogenesi and Gene Expression, eds J. Aslam, P. S. Srivastava, and M. P. Sharma (New Delhi: Narosa Publishing House), 146-165.

Sanchez-Fernandez, R., Fricker, M., Corben, L. B., White, N. S., Sheard, N., Leaver, C. J., et al. (1997). Cell proliferation and hair tip growth in the Arabidopsis root are under mechanistically different forms of redox control. Proc. Natl. Acad. Sci. U.S.A. 94, 2745-2750. doi: 10.1073/pnas.94.6.2745

Schrader, M., and Fahimi, H. D. (2006). Peroxisomes and oxidative stress. Biochim. Biophys. Acta 1763, 1755-1766. doi: 10.1016/j.bbamcr.2006.09.006

Schriner, S. E., Linford, N. J., Martin, G. M., Treuting, P., Ogburn, C. E., Emond, M., et al. (2005). Extension of murine life span by overexpression of catalase targeted to mitochondria. Science 308, 1909-1911. doi: 10.1126/science.11 06653

Schumann, U., Prestele, J., O'Geen, H., Brueggeman, R., Wanner, G., and Gietl, C. (2007). Requirement of the C3HC4 zinc RING finger of the Arabidopsis PEX10 for photorespiration and leaf peroxisome contact with chloroplasts. Proc. Natl. Acad. Sci. U.S.A. 104, 1069-1074. doi: 10.1073/pnas.0610402104

Sheahan, M. B., McCurdy, D. W., and Rose, R. J. (2005). Mitochondria as a connected population: ensuring continuity of the mitochondrial genome during plant cell dedifferentiation through massive mitochondrial fusion. Plant J. 44, 744-755. doi: 10.1111/j.1365-313X.2005.02561.x

Sheahan, M. B., Rose, R. J., and McCurdy, D. W. (2004). Organelle inheritance in plant cell division: the actin cytoskeleton is required for unbiased inheritance of chloroplasts, mitochondria and endoplasmic reticulum in dividing protoplasts. Plant J. 37, 379-390. doi: 10.1046/j.1365-313X.2003.01967.x

Sheahan, M. B., Rose, R. J., and McCurdy, D. W. (2007a). Actin-filamentdependent remodeling of the vacuole in cultured mesophyll protoplasts. Protoplasma 230, 141-152. doi: 10.1007/s00709-006-02635-5

Sheahan, M. B., Rose, R. J., and McCurdy, D. W. (2007b). Mechanisms of organelle inheritance in dividing plant cells. J. Int. Plant Biol. 49, 1208-1218. doi: 10.1111/j.1672-9072.2007.00523.x

Sheen, J. (2001). Signal transduction in maize and Arabidopsis mesophyll protoplasts. Plant Physiol. 127, 1466-1475. doi: 10.1104/pp.010820

Simmonds, D. H., Setterfield, G., and Brown, D. L. (1983). "Reorganisation of microtubules in protoplasts of Vicia hajastana Grossh. during the first 48 hours of culturing," in Protoplasts 1983, eds I. Potrykus, C. T. Harms, A. Hinnen, R. Hütter, P. J. King, and R. D. Shillito (Basel: Springer), 212-213.

Smith, I. K. (1985). Stimulation of glutathione synthesis in photorespiring plants by catalase inhibitors. Plant Physiol. 79, 1044-1047. doi: 10.1104/pp.79.4.1044

Subramani, S. (1993). Protein import into peroxisomes and biogenesis of the organelle. Annu. Rev. Cell Biol. 9, 445-478. doi: 10.1146/annurev.cb.09.110193. 002305

Takebe, I., Labib, G., and Melchers, G. (1971). Regeneration of whole plants from isolated mesophyll protoplasts of tobacco. Naturwissenschaften 58, 318-320. doi: 10.1007/BF00624737

Thomas, M. R., and Rose, R. J. (1983). Plastid number and plastid structural changes associated with tobacco mesophyll protoplast culture and plant regeneration. Planta 158, 329-338. doi: 10.1007/BF00397335

Van Gestel, K., Kohler, R. H., and Verbelen, J. P. (2002). Plant mitochondria move on F-actin, but their positioning in the cortical cytoplasm depends on both F-actin and microtubules. J. Exp. Bot. 53, 659-667. doi: $10.1093 /$ jexbot/53.369.659

Wada, M., and Suetsugu, N. (2004). Plant organelle positioning. Curr. Opin. Plant Biol. 7, 626-631. doi: 10.1016/j.pbl.2004.09.005

Wang, X. D., Nolan, K. E., Irwanto, R. R., Sheahan, M. B., and Rose, R. J. (2011). Ontogeny of embryogenic callus in Medicago truncatula: the fate 
of the pluripotent and totipotent stem cells. Ann. Bot. 107, 599-609. doi: $10.1093 / \mathrm{aob} / \mathrm{mcq} 269$

Waterham, H. R., Titorenko, V. I., Swaving, G. J., Harder, W., and Veenhuis, M. (1993). Peroxisomes in the methylotrophic yeast Hansenula polymorpha do not necessarily derive from pre-existing organelles. EMBO J. 12, 4785-4794.

Yoo, S. D., Cho, Y. H., and Sheen, J. (2007). Arabidopsis mesophyll protoplasts: a versatile cell system for transient gene expression analysis. Nat. Protoc. 2, 1565-1572. doi: 10.1038/nprot.2007.199

Zhang, J., and Kirkham, M. B. (1996). Antioxidant responses to drought in sunflower and sorhum seedlings. New Phytol. 132, 361-373. doi: 10.1111/j.14691837.1996.tb01856

Zhao, J., Morozova, N., Williams, L., Libs, L., Avivi, Y., and Grafi, G. (2001). Two phases of chromatin decondensation during dedifferentiation of plant cells: distinction between competence for cell fate switch and a commitment for S phase. J. Biol. Chem. 276, 22772-22778. doi: 10.1074/jbc.M101756200

Conflict of Interest Statement: The authors declare that the research was conducted in the absence of any commercial or financial relationships that could be construed as a potential conflict of interest.

Copyright $(92015$ Tiew, Sheahan and Rose. This is an open-access article distributed under the terms of the Creative Commons Attribution License (CC BY). The use, distribution or reproduction in other forums is permitted, provided the original author(s) or licensor are credited and that the original publication in this journal is cited, in accordance with accepted academic practice. No use, distribution or reproduction is permitted which does not comply with these terms. 